\title{
Interpreting historical, botanical, and geological evidence to aid preparations for future floods
}

\author{
Bruno Wilhelm $^{1}$ (D) | Juan Antonio Ballesteros Cánovas,3 | Neil Macdonald ${ }^{4}$ | Willem H.J. Toonen ${ }^{5,6}$ \\ Victor Baker $^{7}$ | Mariano Barriendos ${ }^{8}$ | Gerardo Benito ${ }^{9}$ | Achim Brauer ${ }^{10}$ | Juan Pablo Corella ${ }^{11}$ | \\ Rhawn Denniston $^{12}$ | Rüdiger Glaser ${ }^{13}$ | Monica Ionita ${ }^{14}$ | Michael Kahle ${ }^{13}$ | Tao Liu ${ }^{15}$ |

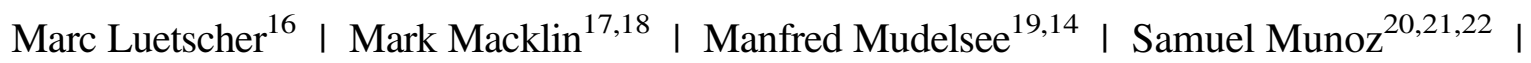 \\ Lothar Schulte $^{23}$ | Scott St. George ${ }^{24}$ | Markus Stoffel ${ }^{2,3,25}$ | Oliver Wetter ${ }^{26}$
}

\footnotetext{
${ }^{1}$ Institute for Geosciences and Environmental Research, University Grenoble Alpes, CNRS, IRD, G-INP, Grenoble, France

${ }^{2}$ Climatic Change Impacts and Risks in the Anthropocene (C-CIA), Institute for Environmental Sciences, University of Geneva, Geneva, Switzerland

${ }^{3}$ Dendrolab.ch, Department of Earth Sciences, University of Geneva, Geneva, Switzerland

${ }^{4}$ Department of Geography and Planning, School of Environmental Sciences, University of Liverpool, Liverpool, UK

${ }^{5}$ Department of Geography and Earth Sciences, Aberystwyth University, Penglais Campus, Aberystwyth, UK

${ }^{6}$ Egyptology Department, Faculty of Arts, Katholieke Universiteit Leuven, Leuven, Belgium

${ }^{7}$ Department of Hydrology and Atmospheric Sciences, University of Arizona, Tucson, Arizona

${ }^{8}$ Department of History and Archaeology, University of Barcelona, Barcelona, Spain

${ }^{9}$ National Museum of Natural Sciences, Spanish Research Council (CSIC), Madrid, Spain

${ }^{10}$ GFZ German Research Centre for Geosciences, Section 5.2 CLimate Dynamics and Landscape Evolution, Potsdam, Germany

${ }^{11}$ Department of Atmospheric Chemistry and Climate, Institute of Physical Chemistry Rocasolano, CSIC, Madrid, Spain

${ }^{12}$ Department of Geology, Cornell College, Mount Vernon, Iowa

${ }^{13}$ Geographie, University of Freiburg, Germany

${ }^{14}$ Alfred Wegener Institute, Helmholtz Center for Polar and Marine Research, Bremerhaven, Germany

${ }^{15}$ Department of Hydrology and Atmospheric Sciences J.W. Harshbarger Building, University of Arizona, Tucson, Arizona

${ }^{16}$ Swiss Institute for Speleology and Karst Studies (SISKA), University of Innsbruck, Institute of Geology, Innsbruck, Austria

${ }^{17}$ School of Geography and Lincoln Centre for Water and Planetary Health, University of Lincoln, Lincoln, UK

${ }^{18}$ Innovative River Solutions, Institute of Agriculture and Environment, Massey University, Palmerston North, New Zealand

${ }^{19}$ Climate Risk Analysis, Bad Gandersheim, Germany

${ }^{20}$ Department of Geology \& Geophysics, Woods Hole Oceanographic Institution, Woods Hole, Massachusetts

${ }^{21}$ Department of Marine \& Environmental Sciences, Northeastern University, Boston, Massachusetts

${ }^{22}$ Department of Civil \& Environmental Engineering, Northeastern University, Boston, Massachusetts

${ }^{23}$ Department of Physical and Regional Geography and ICREA, University of Barcelona, Barcelona, Spain

${ }^{24}$ Department of Geography, Environment, and Society, University of Minnesota, Minneapolis, Minnesota

${ }^{25}$ Department F.-A. Forel for Aquatic and Environmental Sciences, University of Geneva, Geneva, Switzerland

${ }^{26}$ Historisches Institut and Oeschger Center for Climate Change Research, University of Bern, Bern, Switzerland
}

\section{Correspondence}

Bruno Wilhelm, Institute for Geosciences and Environmental Research, University Grenoble Alpes, CNRS, IRD, G-INP, Grenoble, France. Email: bruno.wilhelm@univ-grenoble-alpes.fr

Funding information

Université Grenoble Alpes; Grenoble-INP;

European Geosciences Union; Swiss Academy of Sciences; US National Science Foundation; Past

Global Changes
River flooding is among the most destructive of natural hazards globally, causing widespread loss of life, damage to infrastructure and economic deprivation. Societies are currently under increasing threat from such floods, predominantly from increasing exposure of people and assets in flood-prone areas, but also as a result of changes in flood magnitude, frequency, and timing. Accurate flood hazard and risk assessment are therefore crucial for the sustainable development of societies worldwide. With a paucity of hydrological measurements, evidence from the field 
offers the only insight into truly extreme events and their variability in space and time. Historical, botanical, and geological archives have increasingly been recognized as valuable sources of extreme flood event information. These different archives are here reviewed with a particular focus on the recording mechanisms of flood information, the historical development of the methodological approaches and the type of information that those archives can provide. These studies provide a wealthy dataset of hundreds of historical and palaeoflood series, whose analysis reveals a noticeable dominance of records in Europe. After describing the diversity of flood information provided by this dataset, we identify how these records have improved and could further improve flood hazard assessments and, thereby, flood management and mitigation plans.

This article is categorized under:

Science of Water $>$ Water Quality

Engineering Water $>$ Planning Water

Science of Water $>$ Methods

\section{KEYWORDS}

Flood hazard, historical archive, natural archive, palaeoflood evidence

\section{1 | INTRODUCTION}

Several regions of the world have recently experienced catastrophic flooding, including central Europe, eastern Russia, and northern China in 2013, and the United States and southern Asia in 2017. Flooding is the most common type of natural disaster (43\% of all disasters for period 1994-2013; CRED, 2015), affects more people worldwide than any other natural hazards (2.3 billion people for the period 1994-2013; CRED, 2015), and results in economic losses amounting to approximately 50 billion USD per year on average (Aon Benfield, 2016). These impacts illustrate the vulnerability of modern societies to hydrological extremes, emphasizing the need for improvement in our ability to predict the occurrence of such extreme floods (Blöschl, Nester, Komma, Parajka, \& Perdigão, 2013).

Vulnerability to riverine flooding is growing as a result of increasing exposure of people and infrastructure in flood-prone areas (Kundzewicz et al., 2014). Climate change is expected to exacerbate flood hazard through an intensification of the hydrological cycle, which will likely alter the magnitude, frequency, and/or seasonality of riverine flooding (Blöschl et al., 2017; Seneviratne et al., 2014), although still considerable uncertainty remains over the direction and strength of these shifts (Kundzewicz et al., 2016). Accurate assessments of current and projected flood hazard are thus critical for societies to prepare for future events.

Of growing concern to hydrologists is the need to understand flood hazard and its variability through time and in different catchments (Hall et al., 2014; Merz et al., 2014). Addressing this need remains highly challenging because instrumental data recorded at gauging stations are geographically sparse, discontinuous, affected to varying degrees by human modifications to drainage networks, and rarely span more than a century (Hall et al., 2014; Seneviratne et al., 2014). Over the past few decades, the field of palaeoflood hydrology has expanded to include a variety of historical, botanical, and geological archives that provide critical information describing past floods, particularly high magnitude events that occurred prior to systematic instrumental records (Baker, 2008). Despite their demonstrated ability to improve estimates of flood risk, historical and palaeoflood hydrology remains underutilized in flood hazard assessments (Benito et al., 2004; Kjeldsen et al., 2014). In this study, we (a) provide an overview of available archives that provide information about past floods and (b) describe the ability of these archives to improve the assessment of flood hazards.

\section{2 | THE FLOOD ARCHIVE}

Hereafter, the various flood archives are described with a particular focus on the recording mechanisms of flood information, the historical development of the methodological approaches and the type of information that those archives can provide. 


\section{1 | Historical documents}

Historical records of floods can be found in a wide range of forms, such as annals, chronicles, memorial books, memoirs, newspapers, journals, diaries, accounting books or weather journals, pamphlets, technical reports, flood maps, images (paintings, engravings and photographs) and epigraphic marks (Brázdil, Kundzewicz, \& Benito, 2006; Glaser et al., 2010). With respect to the generation of these records one needs to differentiate between individual and institutional origins (Pfister, 2009). Individual records are shaped by the social background, the motivations and preferences of the record producers (authors). Their temporal scope is limited, at least the one in which they can be considered as contemporaries to the events they describe, to the lifetime of the observer. Institutional sources on the other hand are produced by governments or other bodies and institutions, for example, the church. These institutional bodies were typically not interested in describing weather and climate or single extreme events, but kept records in order to document their activities and in doing so, they indirectly recorded climate and weather related aspects such as floods. The development of technical service bodies either as part of, or affiliated to government, from the eighteenth century in parts of Europe and North America resulted in a proliferation of technical reports. The temporal range of historical flood information found in documentary sources can range from several millennia to the near contemporary, though the majority of the studies focus on the period since ca. AD 1250 (Sangster, Jones, \& Macdonald, 2018), reflecting increased preservation and recording frequency. Record preservation and initial recording are a function of several human factors, including the presence of literate individuals, purpose or cause of interest in the flood event and document preservation, as such the earliest accounts are often, but not exclusively, based in urban areas with either monastic/religious houses, political centres or are important trade locations (Pötzsch, 1784).

Historical flood records have long been of interest, with many city histories written in the eighteenth and nineteenth centuries across Europe collating records of memorable past flood events, though these were not verified to current standards. Some of the earliest analytical studies were undertaken by engineers, in attempting to determine levels for structure design for example, bridges and quays or in the aftermath of catastrophic flood events (Pötzsch, 1784). The discipline of historical hydrology has developed extensively within the last couple of decades (Benito, Brázdil, Herget, \& Machado, 2015). Early historical flood studies were often not published, appearing instead as gray literature or internal reports (Potter, 1964). The statistical incorporation of historical flood information into flood frequency analysis was initially addressed in the 1970s (Leese, 1973) and developed further in the 1980s (Stedinger \& Cohn, 1986), with a later expansion and development of new approaches and techniques for the analysis of historical and augmented flood series (Salinas, Kiss, Viglione, Viertl, \& Blöschl, 2016). In recent years, the development of online databases and resources (e.g., the British Hydrological Society's "Chronology of British Hydrological Events", http://cbhe.hydrology.org.uk; the French "Le répertoire des repères de crues", https://www. reperesdecrues.developpement-durable.gouv.fr; the French-German "Observatoire Régional des Risques d'inondation", http:// orrion.fr/\#; the Swiss "Euro-Climhist database," https://www.euroclimhist.unibe.ch/de and the international www.tambora. org) have facilitated greater adoption of historical analysis and reduced the time consuming nature of historical archive research, though careful analysis of materials are still required. The development of such databases has been somewhat piecemeal, reflecting national developments and/or projects, resulting in different forms of database.

While many studies focus on a single flood event (Demarée, 2006), single catchments or locations (Kiss \& Laszlovszky, 2013), others have examined historical flooding at regional or national scales (Wetter et al., 2011), each providing an opportunity to explore different questions. Historical records can provide a wealth of information. They stand apart from palaeohydrological approaches as they contain information on the physical characteristics, but also often include information concerning the human consequences of floods. Historical sources may permit a detailed analysis of the development, course and consequences of a single, or multiple flood events, including information detailing the underlying meteorological causes, type and dimension of damage and societal impacts and subsequent reactions. The breadth of material included within the historical records can be assessed at a high spatiotemporal resolution, enabling such information to be used in the re-evaluation and estimation of risk, vulnerability and resilience. Where single sites or regions are analyzed over long timescales, additional aspects including flood magnitudes (Wetter et al., 2011), flood seasonality (Macdonald, Kjeldsen, Prosdocimi, \& Sangster, 2014), hydraulic channel changes (Herget \& Meurs, 2010), land-use impact (Böhm \& Wetzel, 2006), and flood generating mechanisms (Jacobeit, Glaser, Luterbacher, \& Wanner, 2003) may be examined through the historical period, improving current understanding of the largest flood events (Benito, Brázdil, et al., 2015). Institutional records containing flood information often have significantly increased "observation skills" toward smaller and "normal" flood events compared to individual records (Wetter, 2017).

Methods in historical flood research are based on hermeneutic as well as quantitative approaches and are interdisciplinary in nature. Following the identification of sources, a critical source analysis by hermeneutic principles is applied, addressing the contemporary socio-political circumstances and the authors' intention, education, and perception (Himmelsbach, Glaser, Schoenbein, Riemann, \& Martin, 2015). The exercise of historical sources critique for historical climatological and historical hydrological purposes includes the correction of calendar style (Julian to Gregorian) and the distinction between contemporary 


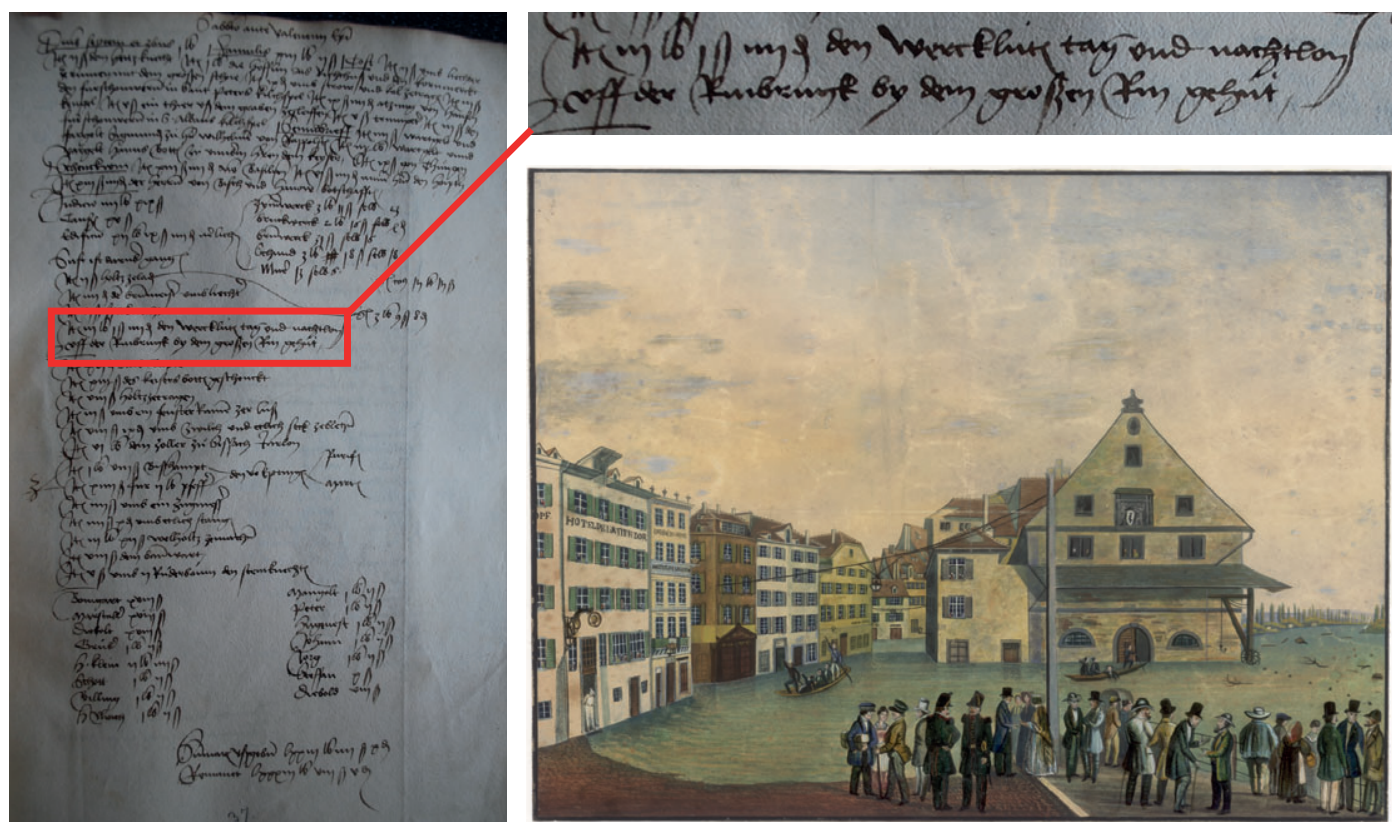

FIGURE 1 Compilation of different documentary flood evidence. (left) extract from the books of weekly expenditures of the City of Basel (Wochenausgabenbücher der Stadt Basel; 1401-1799; Basler Staatsarchiv; Signatur: StaBS Finanz G17) which provide indirect information about past floods such as flood-related costs for guarding a bridge from driftwood during a flood event (top) "paid $3 \mathrm{lb} 1 \mathrm{~s}$ for day and night wages for the craftsmen on the bridge". (right) painting of the "great Rhine" flood event of 18 September 1852 by Louis Dubois (Basler Staatsarchiv; Signatur: StaBS XIII 323)

and noncontemporary sources. Noncontemporary sources generally need to be treated as sources of substantial lower reliability and should only be included for analysis if they provide additional and coherent information based on contemporary sources, of an already known event. The information may then be used to either reconstruct water level, extent, discharge (Figure 1) or be coded into semi-quantitative indices, if required, and calibrated with early-instrumental and more recent measurements to derive objective and quantitative time series. While there are issues concerning spurious and erroneous recording, good archival practice and triangulation help address these concerns, improving the reliability of the derived series (Barriendos \& Rodrigo, 2006). The last two decades have witnessed a rapid expansion in the use of historical flood information in understanding extreme flood events. Historical records are a valuable resource that can help bridge between instrumental and palaeohydrological data (Benito, Ouarda, \& Bárdossy, 2005), providing a mechanism by which extreme floods, events of a magnitude which may not have occurred within the instrumental period, can be calibrated to those contained within palaeohydrological sequences (Werritty, Paine, Macdonald, Rowan, \& McEwen, 2006). The potential for augmentation of instrumental (often gauged) data with historical information provides considerable advantages in risk analysis of extreme events and is increasingly being adopted across Europe as good practice (Kjeldsen et al., 2014).

\section{2 | Tree rings}

Trees preserve evidence of past floods because floodwaters have a direct effect on tree growth, form and survival. The use of trees as palaeoflood indicators is based on the "process-event-response" concept, where the "process" represents a specific flood, the "event" is the resulting tree disturbance (i.e., abrasion scars, abnormal stem morphologies, eroded roots, tilted stems, standing dead trees, etc.), and the "response" refers to the physiological response of trees to the disturbance, which results in a specific anatomical imprint created within the tree's annual growth rings (Ballesteros-Cánovas, Stoffel, St George, \& Hirschboeck, 2015; Stoffel \& Corona, 2014). Scars on tree trunks are the most common evidence of past flood activity in trees. Scars are caused by the impact and abrasion of debris and wood transported during floods. Injuries caused by scars leave on treerings a variety of growth and anatomical signatures which depend on the species, such as traumatic resin ducts, changes in vessel size or callus tissues (Arbellay, Fonti, \& Stoffel, 2012; Ballesteros-Cánovas et al., 2010). These features can be used to identify the year of past floods, and sometimes even determine the season of flooding (Stoffel \& Corona, 2014). Thus, the height of scars is interpreted as palaeostage indicator of a flood and can be used to derive peak discharge estimations (Ballesteros-Cánovas et al., 2011). Floods also tilt trees when the hydrodynamic pressure induced by high flows exceeds the stem elasticity and root-plate system anchorage. Since tilted trees will compensate their deviation of the vertical growth by forming reaction wood and eccentric growth (Timell, 1986), they can be used not only as a proxy for past floods (Sigafoos, 1964: Gottesfeld \& Johnson Gottesfeld, 1990), but also as a means to estimate flow discharge (Ballesteros-Cánovas et al., 2014). Other palaeoflood evidence recorded by trees include: (a) abrupt decreases in tree-ring widths due to trees being 

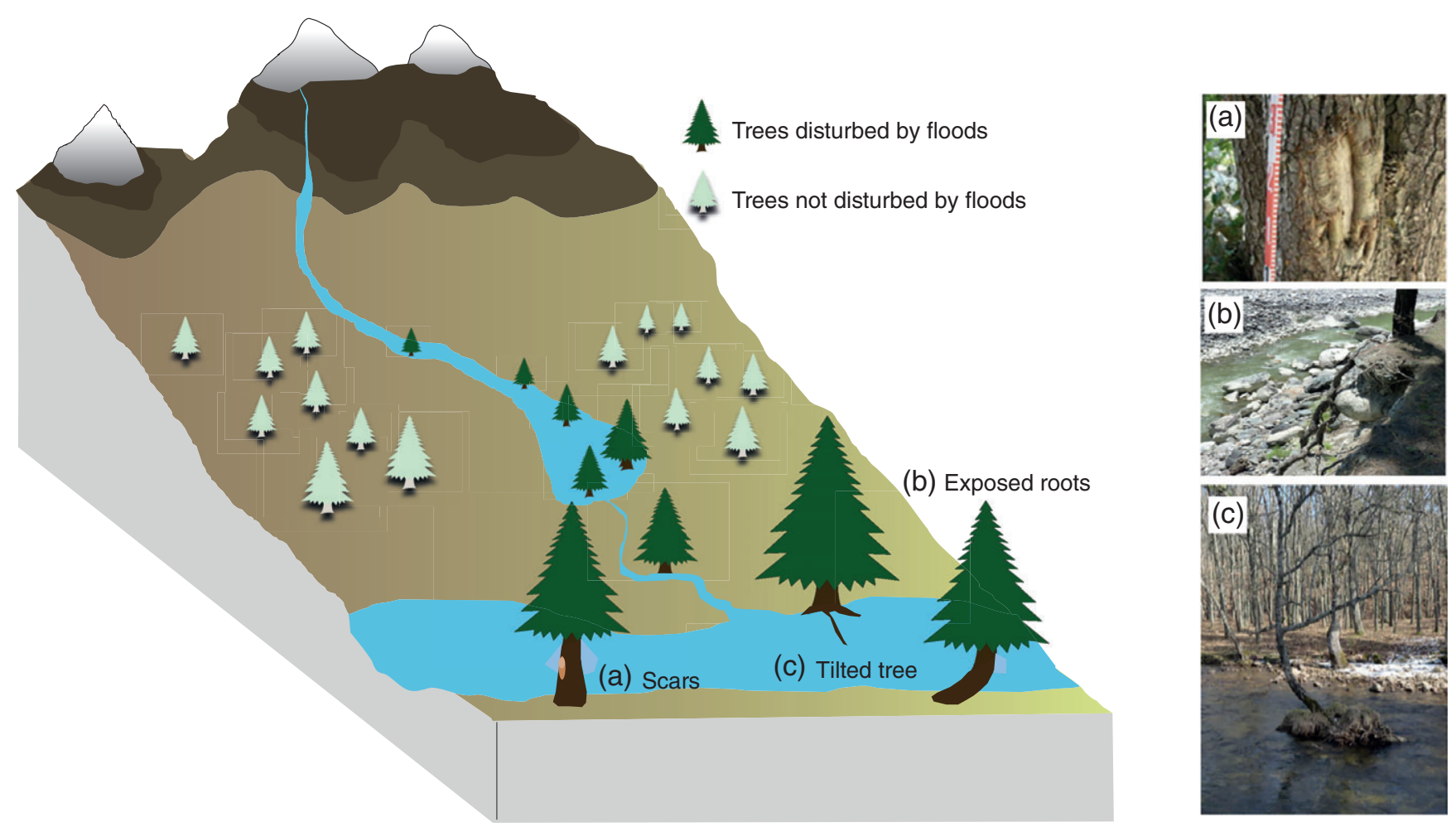

FIGURE 2 Schematic illustration showing the most common ways that riparian trees are disturbed or damaged by floods; (a) flood-rafted debris cause trees to form scars because of impact or abrasion, (b) floodwaters undercut bankside trees and expose the roots, and (c) tree stems become distorted or "tilted" by hydrodynamic pressure from high flows

partially buried by fluvial sediments, which limits their nutrient supplies and ability to take in water (Friedman, Vincent, \& Shafroth, 2005; Kogelnig, Stoffel, \& Schneuwly-Bollschweiler, 2013), (b) wood anatomical changes in roots caused by their exposure due to bank erosion (Malik, 2006), and (c) anatomical abnormalities produced when trees are inundated for several weeks during the early growing season (St. George, Nielsen, Conciatori, \& Tardif, 2002; Wertz, St. George, \& Zeleznik, 2013).

The potential for flood-affected trees to act as botanical archives of past floods was first described on the Potomac River near Washington, DC (USA) to extend flow records for hazard assessments (Sigafoos, 1961). This approach was then extended to the northern part of California to provide a 400-year flood chronology (Helly \& LaMarche Jr, 1973). The extension of flood records based on tree rings was then used to improve flood frequency analysis (Harrison \& Reid, 1967). In the subsequent decades, several efforts have been done to understand the physiological responses of trees to flooding (Kozlowski, 1997; St. George et al., 2002; St. George \& Nielsen, 2003) and the interactions between geomorphology and riparian trees Ballesteros-Cánovas et al., 2015). In northern North America, scarred trees have widely been used to study the effects of ice jamming on hydrology and hydraulics during early spring floods (Egginton \& Day, 1977; Tardif \& Bergeron, 1997). In the past decade, the use of trees and tree-ring records to provide surrogate flood information has been expanded geographically (Ballesteros-Cánovas, Trappmann, Shekhar, Bhattacharyya, \& Stoffel, 2017; Therrell \& Bialecki, 2015; Zaginaev et al., 2016; Zielonka, Holeksa, \& Ciapala, 2008).

Tree rings can provide information about the timing of past flood occurrence (usually with annual precision, but in some cases resolved to seasonal precision) as well as the flood magnitude. In temperate and boreal regions where trees form a distinct growth ring each year, it is possible to date floods through a combination of ring counting and pattern matching. Floods may be dated to a particular season if the growth anomalies caused by flooding can be resolved to a specific location within the annual ring: early-earlywood (event occurred during the prior dormant period); earlywood (event occurred during the earliest stage of growing season); early-latewood (first stage of the late growing season) and late-latewood (floods took place during the final part of the growing season) (Stoffel \& Corona, 2014). In addition to providing annual dates, tree rings have been also used to estimate flood magnitudes in combination with palaeohydraulic techniques (Gottesfeld, 1996). Recently, twodimensional hydraulic models and the height of dated scars on trees have been used to understand the genesis of scars and its relation to flood peak discharge in contrasting fluvial environments. Scars may be used as a factor of the tree location within the reach river (Ballesteros-Cánovas et al., 2015). Moreover, the degree of deformation of trees has been used as an 
explanatory variable to decipher the flood magnitude based on a mechanistic model in different rivers and tree species Ballesteros-Cánovas et al., 2014).

In part because of trees' affinity to riparian environments, tree rings are well suited to provide information about flood occurrence and magnitude during the past few centuries. Thus, due to the annual or seasonal resolution of this archive, the reliability of tree-based palaeoflood estimates has been directly compared against flood sequences from historical accounts and instrumental discharge records on specific fluvial system and on a broader spatial scale (Ballesteros-Cánovas et al., 2017; Munoz et al., 2018; St George \& Nielsen, 2000; Therrell \& Bialecki, 2015). Tree-ring evidence often provides a censored record of past floods, as high-magnitude floods are more likely to damage trees or alter their growth or stem architecture than smaller events, and can, under some circumstances, be biased toward floods that occur during the growing season (St. George \& Nielsen, 2003 St George, 2010). The reliability of tree-based palaeoflood estimates have been tested against historical accounts and instrumental flood records. In general, the accuracy of this approach depends in part on tree age and species (Tichavský, Šilhán, \& Stoffel, 2017). Because riparian trees can be damaged by other causes (e.g., human activities), trees must be selected carefully to minimize the influence of nonflood signals. Moreover, because flood damage can vary between neighboring trees, samples must be taken from a minimum number of trees to replicate the flood signals and develop reliable estimates of past flood events (Ballesteros-Cánovas et al., 2015; Tichavský et al., 2017). Although sampling approach is the key factor to establish a reliable flood chronology, with regard to estimates of flood magnitude, the main source of uncertainty is the difference between high water stage of the flood and the maximum scar height. Difference between observed on trees and measured water stage may vary with the flood magnitude, tree location, and the dominant transport sediment mechanism (Ballesteros-Cánovas et al., 2011; Gottesfeld, 1996; Yanosky \& Jarrett, 2002). Further post-event assessments could contribute to range these uncertainties in different geomorphologic environments and improve the efficiency of the sampling procedures to reduce methodological uncertainty in the flow estimation using palaeostage indicators from trees (Ballesteros-Cánovas et al., 2015; Yanosky \& Jarrett, 2002).

\section{3 | Speleothems}

Speleothems are cave mineral deposits such as stalagmites and flowstones, and are widely used as palaeoclimate records (Wong \& Breecker, 2015). They also hold potential to serve as precise records of past flood events as they form continuous records over centuries to millennia, resist being dissolved or recrystallized, and are well-suited for radiometric dating by ${ }^{238} \mathrm{U}_{-}{ }^{234} \mathrm{U}_{-}{ }^{230} \mathrm{Th}$ disequilibrium analysis (hereafter U-Th)(Denniston \& Luetscher, 2017). When cave floodwaters submerge speleothems, a coating of water-borne detritus may be deposited on growth surfaces (Atkinson, Lawson, Smart, Harmon, \& Hess, 1986). After water recedes and speleothem deposition is re-initiated, this detritus is trapped within the speleothem along a single growth horizon, thereby preserving a record of the flood event. This material can be identified by physical (Denniston et al., 2015) or chemical (Dasgupta et al., 2010) contrasts with the speleothem matrix carbonate. However, care must be taken to differentiate sediments deposited by flooding from other detrital particles including soot (Gradzinski, Hercman, Nowak, \& Bella, 2007), guano (Martinez-Pillado, Aranburu, Yusta, Stoll, \& Arsuaga, 2010), iron oxyhydroxide minerals crystallized on stalagmite growth surfaces (Gázquez et al., 2014), fine-grained eolian sediments (Railsback, Brook, \& Webster, 1999), and soil particles transmitted into the cave along fractures that can easily be misinterpreted as flood events (Belli et al., 2017).

Detrital layers within speleothems have been linked to cave flooding events for several decades (Atkinson et al., 1986; White, 1976), but detailed analysis of flood layers began more recently. For example, a series of visual identification methods including optical and scanning electron microscopy has been integrated to distinguish between fluvial and air-borne grains (Railsback et al., 1999). Geochemical microanalysis has improved on this methodology (Dasgupta et al., 2010; Finné et al., 2014). Together with examination of speleothems, environmental monitoring programs can be used to understand the rainfall thresholds required to trigger cave flooding (Maréchal, Ladouche, \& Dörfliger, 2008), including monitoring of discharge at karst springs and water levels inside the associated cave system (Bättig \& Wildberger, 2007).

The ages of flood layers are determined using growth models constructed from U-Th dating of the speleothem carbonate (Dorale et al., 2004). These dates can be remarkably precise, with two standard deviation errors less than $1 \%$ over the last several hundred thousand years (Wang et al., 2008). In many speleothems, the largest hindrance to achieving precise U-Th dates typically involves corrections for Th not produced within the stalagmite but instead incorporated into the stalagmite when it formed. This "inherited Th" is associated with detritus such as that introduced by flood-derived sediment. In order to develop a meaningful chronology for individual floods preserved within a speleothem, multiple precise dates must be obtained, and thus samples for dating must be milled from intervals with limited detrital components. A balance must struck, therefore, such that stalagmites record a sufficient number of flood events so as to offer a detailed history of cave flooding while also allowing extraction of "clean" carbonate for precise age determinations.

Information about both flood occurrence and magnitude can be extracted from speleothems. One attempt to constrain the magnitude of cave floods from the study of a single stalagmite involved two assumptions: first that the particle size of the 


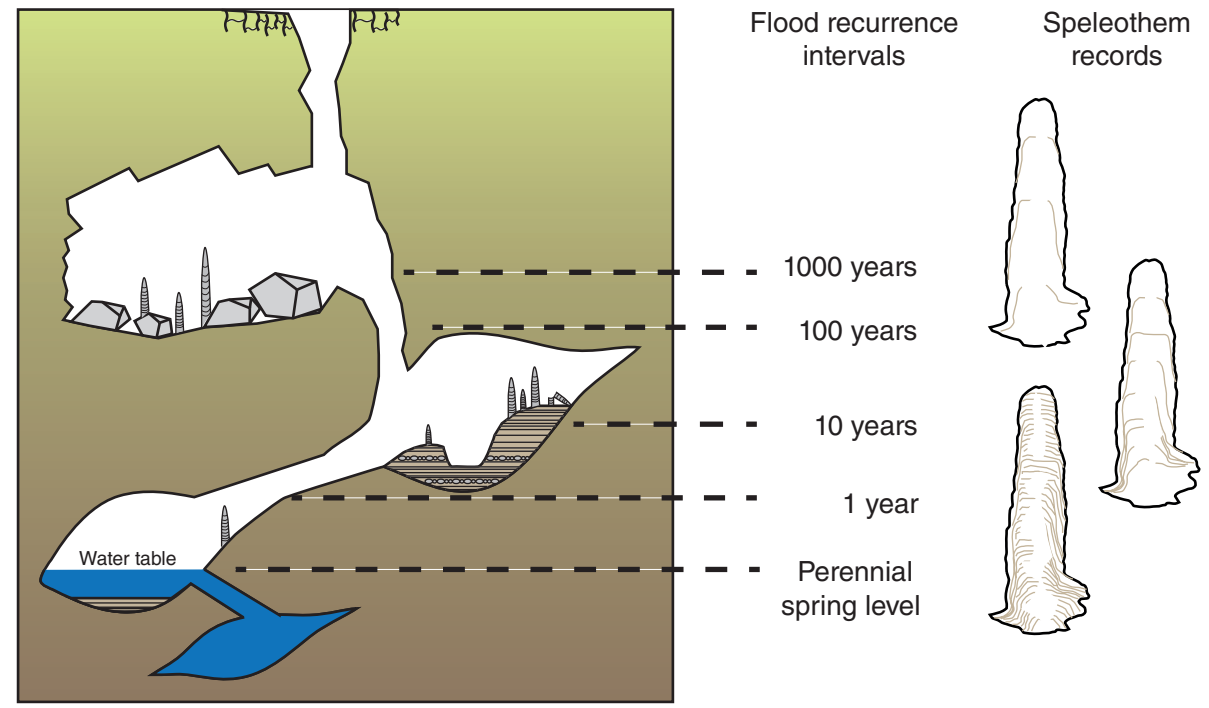

FIGURE 3 Illustration of the flood-recording mechanisms of speleothems in a cave system where water table fluctuations in caves can reach several tens of meters, depending on the hydraulic head loss in the karst system. Such flows deposit sediments on speleothems, which are preserved when flood waters recede and speleothem growth resumes

sediments transported through the cave was proportional to the flood magnitude, and second that the larger floods would regress more slowly than smaller floods, thereby depositing thicker sedimentary packages on stalagmite growth surfaces (González-Lemos et al., 2015). Multiple flood time series reconstructed from stalagmites growing at different levels in the same cave would offer the most robust method for determining variations in flood magnitude (Figure 3).

The ability of individual speleothems to record cave flood events accurately is limited by several factors including the position of the speleothem relative to flood stage, the hydraulics characterizing flood recession, the abundance and nature of cave sediment, the geometry of the speleothem growth surface, and the total energy delivered to the speleothem growth surface by dripwater following flooding (Denniston et al., 2015). Careful selection of speleothems is critical for identifying suitable samples for flood layer analysis. The appropriate elevation within the cave is selected relative to modern flood regimes - too low and too many flood layers may be preserved, complicating U-Th dating; too high and too few floods are recorded, limiting the utility of flood reconstruction analysis (Figure 3). Sampling of stalagmites should always be performed in a manner designed to minimize damage to caves, and thus broken and down samples are preferred if the initial growth position is known. However, analysis of an actively growing speleothem may allow calibration using historical rainfall and/or documented cave flood events. The importance of replication among coeval speleothems is important due to differential preservation of flood sediment between samples (Denniston et al., 2015). Stalagmites appear to represent a more reliable proxy than flowstones given that the latter are typically characterized by complex growth dynamics and morphology and are more likely to incorporate colloidal fractions and detrital sediment transported by normal water flow (Boch \& Spötl, 2011; Meyer, Spötl, Mangini, \& Tessadri, 2012). Fast growing stalagmites (i.e., $\geq 200 \mu \mathrm{m} \mathrm{yr}^{-1}$ ) exposed to flood recurrence intervals of $\geq 10$ years therefore represent highly suitable samples for long-term reconstructions.

\subsection{Lake sediments}

Lake sediments are valuable archives of past floods as they constitute the natural sink for sediments transported during floods. Flooding events erode the soil in the lake's watershed, mobilizing large amounts of sediment that reach the lake basin via diffuse run-off and/or direct river streamflow. The distribution and deposition of these sediments in the lake basin then forms discrete flood deposits. As these deposits are preserved in the lake sedimentary sequences, they constitute continuous archives of past floods (Gilli, Anselmetti, Glur, \& Wirth, 2013). Depending on the sediment-laden flow type after entering the lake, different depositional mechanisms occur and result in different types of flood deposits (Mulder \& Chapron, 2011; Wilhelm, Sabatier, \& Arnaud, 2015). Their common feature is the enrichment in detrital material from soil erosion. In case of organicdominated matrix sediments, this usually results in strong contrasts (e.g., the color) between the flood deposits and the background sediment that make the flood deposit recognition easy under visual description and/or microscopic inspection of sediment cores (Gilli et al., 2013; Støren, Olaf Dahl, Nesje, \& Paasche, 2010). In case of clastic-minerogenic sediments, the contrast is less pronounced and a combination of several textural and geochemical proxies (e.g., grain size, elemental composition, density, organic content, carbon/nitrogen ratio, pollen, isotopic analyses) is required to reveal flood deposits in the sediment record (Gilli et al., 2013; Schillereff, Chiverrell, Macdonald, \& Hooke, 2014). Most flood deposits are also characterized 


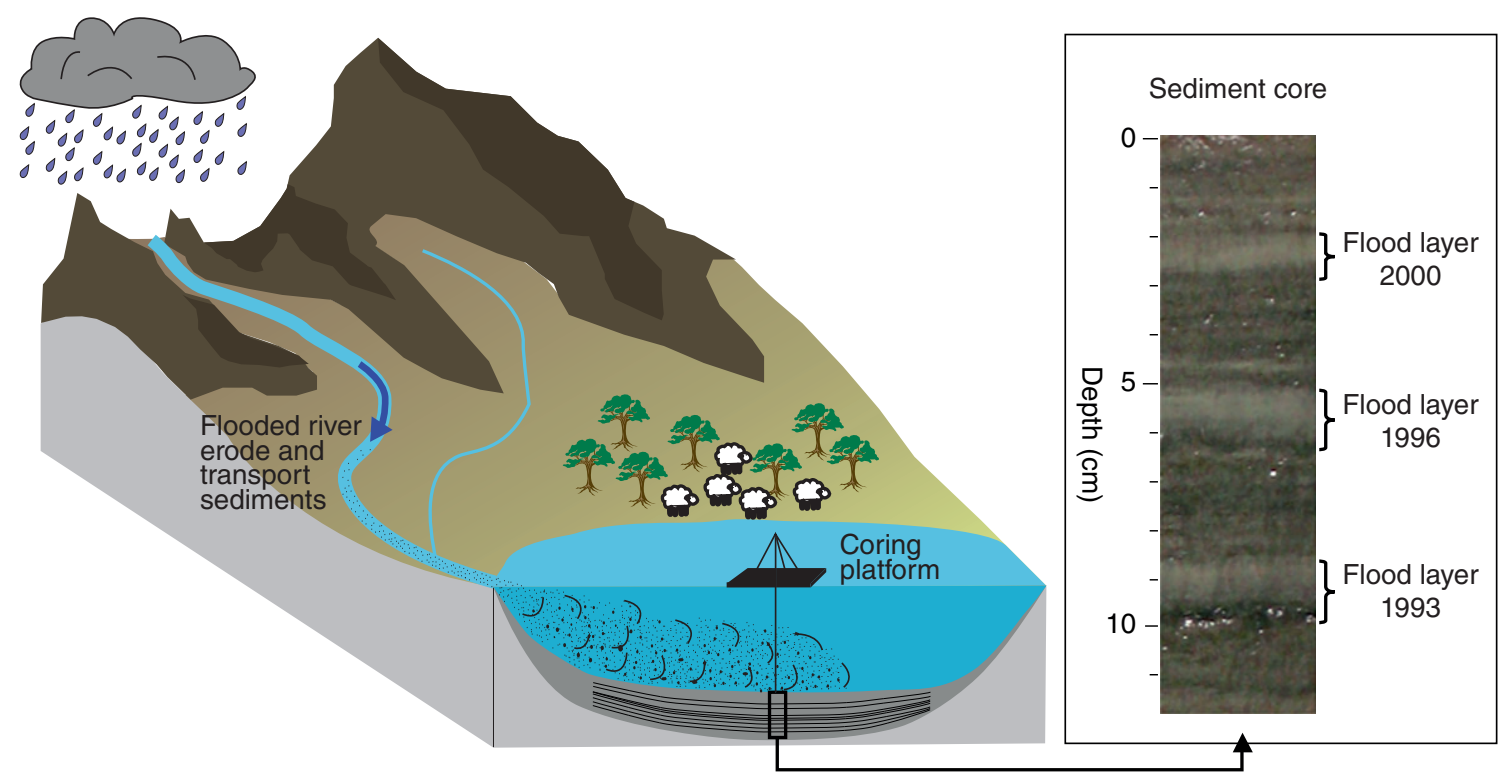

FIGURE 4 Schema of the flood-recording mechanisms of lake sediments (left) and photo of a sediment core from Lago Maggiore (Southern Alps, Italy) showing typical flood layers (right)

by coarser grain sizes than the matrix (Parris, Bierman, Noren, Prins, \& Lini, 2010), providing a tool to reconstruct flood magnitudes as the grain size may represent the river energy and the discharge (Lapointe, Francus, Lamoureux, Sard, \& Cuven, 2012). In particular geological or geomorphological contexts that induce a relatively homogeneous grain size precluding this approach (Wilhelm et al., 2015), the flood magnitude can be reconstructed through the volume of flood triggered sediments (Mulder \& Chapron, 2011). If flood sediments are similarly distributed within the lake basin between flood events, the thickness of flood deposits measured in a single core may be used as a proxy of flood magnitude (Corella, Benito, Rodriguez-Lloveras, Brauer, \& Valero-Garcés, 2014; Page, Trustrum, \& DeRose, 1994; Schiefer, Gilbert, \& Hassan, 2011; Wilhelm et al., 2015). In case of heterogeneous spatial distribution, an adequate spatial coverage with several cores is required for a reliable assessment of the flood-sediment volume (Jenny et al., 2014).

Lacustrine sediment processes during floods have been documented for the first time at the end of the nineteenth century (Forel, 1885). The main sediment-laden flow type that takes place during floods in Lake Geneva have been described and the concept of "plunging river" has been developed. This term corresponds to the plungement of the sediment-laden river waters when entering the lake because of its higher density than the lake waters. This concept was then further developed almost one century later and provided insight of the different flow types and associated depositional mechanisms of sediments during floods (Sturm \& Matter, 1978). A few years later, the first correlation between discharge and occurrence of sedimentary events in Lake Geneva was introduced (Giovanoli, 1990), and the first palaeoflood reconstruction was performed in lake sediments aiming at documenting past climate variability (Rodbell et al., 1999). Following this approach, the first regional flood time series covering the entire Holocene was provided from 14 lakes in the northeastern United States (Noren, Bierman, Steig, Lini, \& Southon, 2002). This was the first use of lakes as sources of palaeoflood information, and this approach has been subsequently applied by many follow-up studies (Arnaud et al., 2016; Wirth, Glur, Gilli, \& Anselmetti, 2013). From the beginning of the 21st century, methodological aspects have been further developed (Gilli et al., 2013; Schillereff et al., 2014). A particularly important milestone was the first identification of hydrological events in varved (i.e.,seasonally laminated) lake sediments through the microstratigraphical position of a detrital layer within an annual couplet (Lamoureux, 1999). This allowed developing palaeoflood reconstructions at the seasonal scale (Czymzik et al., 2013; Swierczynski et al., 2013; Amann, Sönke, \& Grosjean, 2015; Corella, Valero-Garcés, Vicente-Serrano, Brauer, \& Benito, 2016).

Lake sediments provide information about past flood occurrence and magnitude. Reconstructing flood occurrences and frequencies is rather straightforward and mainly based on the recognition of detrital, event layers and the precision of the chronology. The methods and proxies listed above allow the identification of event deposits at a millimeter scale. Careful attention is required to distinguish between event deposits triggered by floods compared to other triggers such as subaquatic landslides (Wilhelm et al., 2016). The precision of the chronology depends on the dating methods applied (e.g., varve counting, shortlived radionuclides, radiocarbon ages, correlation with historical events or palaeomagnetic variations) (Gilli et al., 2013). While seasonal precision can be achieved from varved records, most flood records are at decadal to centennial resolution. Flood magnitude reconstruction requires additional proxies, that is, layer thickness and grain size, and a comprehensive understanding of the sedimentary processes of the lake system. Calibration with instrumental records allows quantitative 
reconstruction of flood occurrence and magnitude, that is, to determine the threshold of precipitation or discharge for detrital layer deposition and the nature of the relationship between proxy and flood discharge (Jenny et al., 2014; Kämpf et al., 2015). Such flood records can extend to previous interglacial periods (Brunck, Sirocko, \& Albert, 2016; Mangili, Brauer, Moscariello, \& Naumann, 2005), but most cover the last millennia.

During the last two decades, numerous calibration studies and reproducibility tests have been performed and strongly support the reliability of palaeoflood reconstructions from lake sediments (Corella et al., 2014; Czymzik et al., 2010; Jenny et al., 2014; Lapointe et al., 2012; Page et al., 1994; Schiefer et al., 2011; Wilhelm et al., 2012; Wilhelm et al., 2015). These studies demonstrated that a large variety of different factors influence the sedimentary processes of each lake system and that a comprehensive understanding of these processes is crucial for reconstructing past floods. However, only a few of the ca. 80 existing flood reconstructions could be calibrated to precipitation and discharge data, because of the scarcity of such data and the overlap with the palaeoflood records are often limited by the short instrumental period. An alternative option to validate flood records and define a relative flood magnitude is the use of historical flood data that extends over longer periods (Wilhelm et al., 2012; Wilhelm, Vogel, Crouzet, Etienne, \& Anselmetti, 2016). Changes of the sedimentary processes in the watershed may bias the sedimentary flood evidence record by modifying the deposition threshold or the relationship between discharge and sediment supply through time. Such changes often depend on anthropogenic activities and associated land-use changes or vegetation cover that control potential surface erosion (Giguet-Covex et al., 2014). Hence, information on anthropogenic activities is essential to reliably interpret flood time series (Mills et al., 2016).

\section{5 | Fluvial sediments}

Alluvial deposits of rivers represent an unwritten flood record (Jones, Macklin, \& Lewin, 2010). Floods rise and fall and leave behind a sediment signature. These deposits include sequences or couplets both of coarse material from peak discharges and fine material from waning flows or inter-flood discharges. Unit thickness may relate to flood duration and magnitude, but also to intra-flood sediment loadings. Sediment spillage into low-energetic fluvial zones (channel margins and overbank zones) can result in the formation and preservation of flood archives. Table 1 lists flood recording riverine sedimentary environments



FIGURE 5 Illustration of the flood-recording riverine sedimentary environments where event-scale palaeoflood records have been reconstructed 
TABLE 1 Flood recording riverine sedimentary environments where event-scale palaeoflood records have been reconstructed. Key publications are listed

\begin{tabular}{|c|c|}
\hline Sedimentary environment & References \\
\hline \multicolumn{2}{|l|}{ Channel and channel margin } \\
\hline Vertical accretion units & Macklin, Rumsby, \& Newson, 1992; Rumsby, 2000 \\
\hline Boulder berms and bars & Macklin, Rumsby, \& Heap, 1992; Rumsby \& Macklin, 1994; Maas \& Macklin, 2002; Foulds \& Macklin, 2015 \\
\hline Lateral accretion units & Brown, Cooper, Salisbury, \& Smith, 2001 \\
\hline \multicolumn{2}{|l|}{ Overbank } \\
\hline Palaeochannel fills & $\begin{array}{l}\text { Knox, 2000; Werritty et al., 2006; Jones, Macklin, \& Brewer, 2012; Macklin et al., 2015; Munoz et al., 2015; } \\
\text { Toonen, Winkels, Cohen, Prins, \& Middelkoop, } 2015\end{array}$ \\
\hline Flood-basin incursions & Knox, 1993; Schulte, Veit, Burjachs, \& Julià, 2009, Schulte et al., 2015; Jones et al., 2010; Macklin et al., 2015 \\
\hline Slack water deposits & Kochel \& Baker, 1982; Benito et al., 2004; Baker, 2008; Harden, O'Connor, \& Driscoll, 2015 \\
\hline
\end{tabular}

that have been used to provide data for event-scale flood histories, in some cases back to the early Holocene. They are variably available within river catchments, and Figure 1 illustrates this in terms both of local depositional environment and catchment location.

Beginning in the first half of the 20th century, fluvial deposits from pre-instrumental floods formed the basis for discharge estimates that were incorporated into flood-frequency analyses (Jahns, 1947). The practice of estimating palaeoflood discharges from fluvial sediments and incorporating these into flood-frequency analyses improved over the late 20th and early 21 st century with advances in hydraulic modeling and statistical techniques (Costa, 1978; Frances, 2004). The advent of advanced dating techniques greatly expanded the fluvial contexts from which information about past flood occurrence could be collected. In the early 21 st century, databases containing hundreds of dated flood units were compiled to reconstruct spatiotemporal patterns of flood activity across catchments of different sizes and regions in relation to historical and Holocene climate variability and land-use changes (Benito et al., 2015; Harden, Macklin, \& Baker, 2010; Macklin et al., 2006, 2015). Improvements in the chronological precision of palaeoflood data derived from fluvial sediments over the last decade has significantly improved flood hazard assessment, including low-frequency high-magnitude events and their climatic forcing (section on "Climate - flood relationships").

Ages can be assigned to flood units based on radiocarbon $\left({ }^{14} \mathrm{C}\right)$ dating of organic material entrained in a fluvial deposit or optically-stimulated luminescence (OSL) dating of sandy grains incorporated in flood sediments. Flood units can also be bracketed by dates to infer ages of flood events (Knox, 1993; Kochel \& Baker, 1982), using age modeling techniques (Jones et al., 2012; Minderhoud, Cohen, Toonen, Erkens, \& Hoek, 2016; Munoz et al., 2015). Other dating techniques that are commonly used to provide flood chronologies over the last 200-300 years are lichenometry ${ }^{133}$ and radiogenic isotopes such ${ }^{210} \mathrm{~Pb},{ }^{137} \mathrm{Cs}$, and ${ }^{7} \mathrm{Be}$ (Ely, Webb, \& Enzel, 1992; Macklin, Rumsby, \& Heap, 1992; Stokes \& Walling, 2003).

Flood magnitude estimates can be determined from fluvial sediments in two ways. Firstly, for boulder berms, lateral and vertically accreted deposits, flood basins, and infilling river channel cut-offs, the texture (grain-size or geochemical proxy for this) of a flood unit can be related to peak flood discharge via statistical and/or hydraulic modeling (Foulds \& Macklin, 2015; Knox, 1993; Macklin, Rumsby, \& Heap, 1992; Toonen et al., 2015). Secondly, in gorges or canyons, slackwater deposit elevation serves as a high-water mark such that a minimum flood magnitude can be estimated using the slope-area method and/or hydraulic modeling (Benito et al., 2004; Kochel \& Baker, 1988), procedures that involve certain uncertainties as assessed by Lumbroso and Gaume (2012).

The use of fluvial sediments as palaeoflood archives is context dependent and requires an understanding of the processes that erode and deposit sediments in a reach or catchment (Toonen et al., 2015). Fluvial systems are dynamic and can be highly sensitive to climate and land-use change, which control water and sediment supply as well as channel and floodplain evolution (Benito et al., 2010; Knox, 2000). A site's suitability for providing information on the frequency and magnitude of past floods is contingent on establishing the vertical and lateral development of river channels and floodplains over the period of the flood record and is best evaluated by comparing multiple sites along a river reach or within a catchment. Riverine sedimentary environments provide an event-scale record of floods with a temporal precision on the order of years, decades and centuries. They favor the preservation of higher-magnitude events in the form of distinct depositional units in river channels, along channel margins, or on floodplains.

\section{3 | THE FLOOD-ARCHIVE DATA, THEIR CURRENT AND POTENTIAL USE}

The study of different archives described previously provides a wealthy dataset of historical and palaeoflood series from all around the world. The following sections aim to provide an overview of this dataset, how it has been developed and could be used in the future to improve flood-hazard assessments. 


\section{1 | Overview of the available data}

A call-for-contribution in the framework of the PAGES Floods Working Group resulted in the identification of 381 published historical and paleoflood records covering at least the last 100 years. Most of these records are derived from historical documents (36\%) and riverine sediments (33\%), with the final third added from studies of lake sediments and tree rings (29\%). A small number of studies (2\%) are provided by relatively new approaches examining speleothems. A large number of historical documents and riverine sediment studies are not included at this stage, as they focus on single flood event at a given location. This study only considers flood series constructed from the various datasets rather than single events, for the purpose of dataset homogeneity allowing data comparison.

\subsection{1 | Data distribution in space and time}

The distribution of the 381 flood records in the world is heterogeneous (Figure 6). More than $60 \%$ of the records document past flood variability in Europe, while North America and Asia are respectively covered by $15-20 \%$ of the records, with a sparse coverage (6\%) in the southern hemisphere (Oceania, South America and Africa). Recent large events, such as the August 2005 flood in Central and Western Europe have stimulated palaeoflood research in Europe, recognizing an opportunity to determine whether recent events are unique in magnitude and recurrence. Moreover, they permit an evaluation of the role of warmer periods in the occurrence of high-impact events (Corella et al., 2016; Glur et al., 2013; Wilhelm et al., 2012). However, improved knowledge of flood hazard is also required in less well documented regions, such as Asia and Africa; with approximately 13,000 people killed by floods in India, Bangladesh, Pakistan and China between 2007 and 2013 (CRED, 2015). Flood risk is exacerbated by dense populations living in flood-prone areas. However, adequate flood hazard assessments are limited by the absence of hydrological observations. Using natural flood archives offers a unique opportunity to provide such missing flood information, as performed for example in South Africa (Benito et al., 2011), Namibia (Greenbaum et al., 2014; Grodek et al., 2013), China (Liu et al., 2014) or Western Indian Himalayas (Ballesteros-Cánovas et al., 2017). The use of natural archives may be extended to any ungauged basins, thereby, helping to solve the problematic issue of establishing predictions (Sivapalan et al., 2003). Beside the spatial distribution of records, the length of records is critical, as longer records permit greater understanding of flood variability and recurrence rates related to rare extreme events. However, uncertainties may also be embedded in longer records as dating uncertainties often increase with time. Furthermore, changes in river morphology and catchment can change over time, influencing for instance fluvial dynamics, sediment load and river discharge. Among the 381 records, almost half (46\%) covers the last hundred(s) of years, while $44 \%$ span the last millennia. Only a few records (10\%) cover the entire Holocene (i.e., last 11,700 years) or more. The distribution by archive type is provided in Figure 7. Depending on available archival sources at the studied location, historical flood records often cover the last couple of centuries and, in the best cases, the last millennia (Seidlmayer, 2001). Flood reconstructions based on tree rings are often limited to the last century because this approach requires living trees, while geological records (speleothem, lake and fluvial sediments) cover longer periods, in most cases the last millennia and in rare cases up to the hundred thousand years.

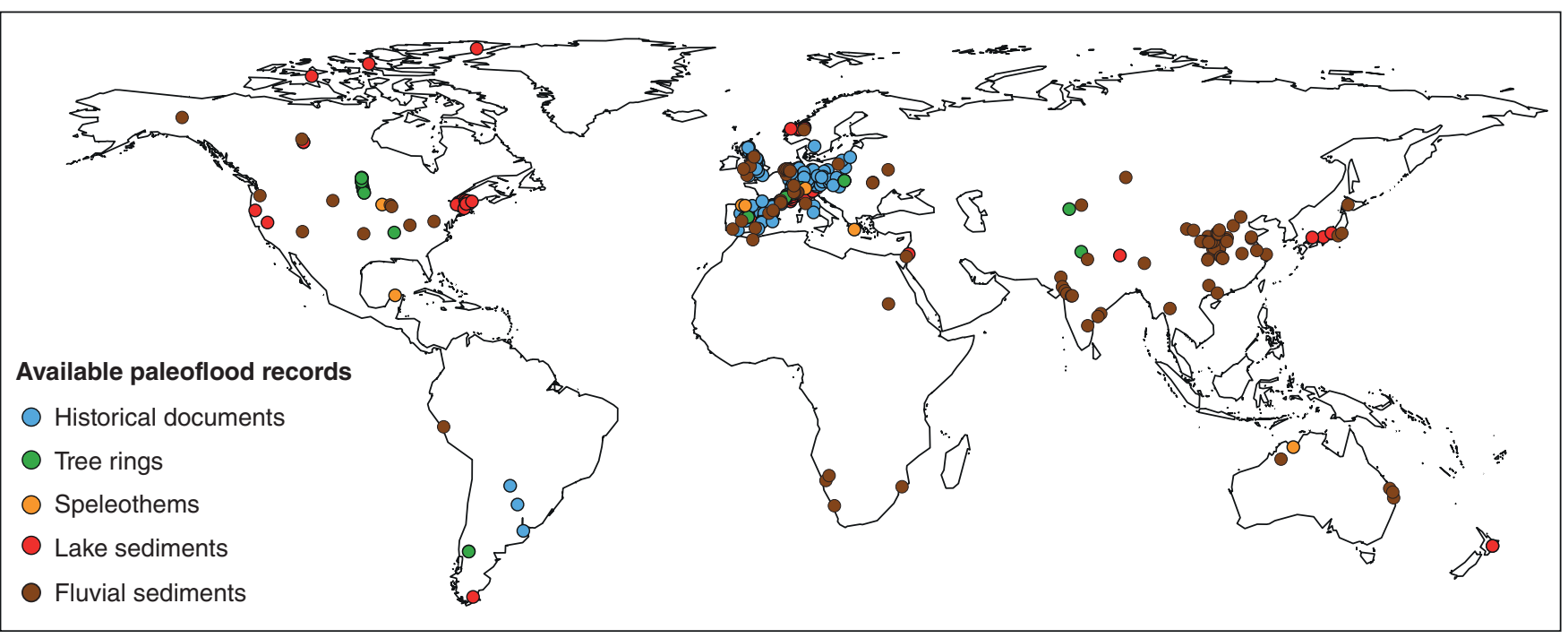

FIGURE 6 Global distribution of historical, botanical and geological flood data. Details of this regularly-updated dataset and its interactive mapping can be found at: http://pastglobalchanges.org/ini/wg/floods/data 


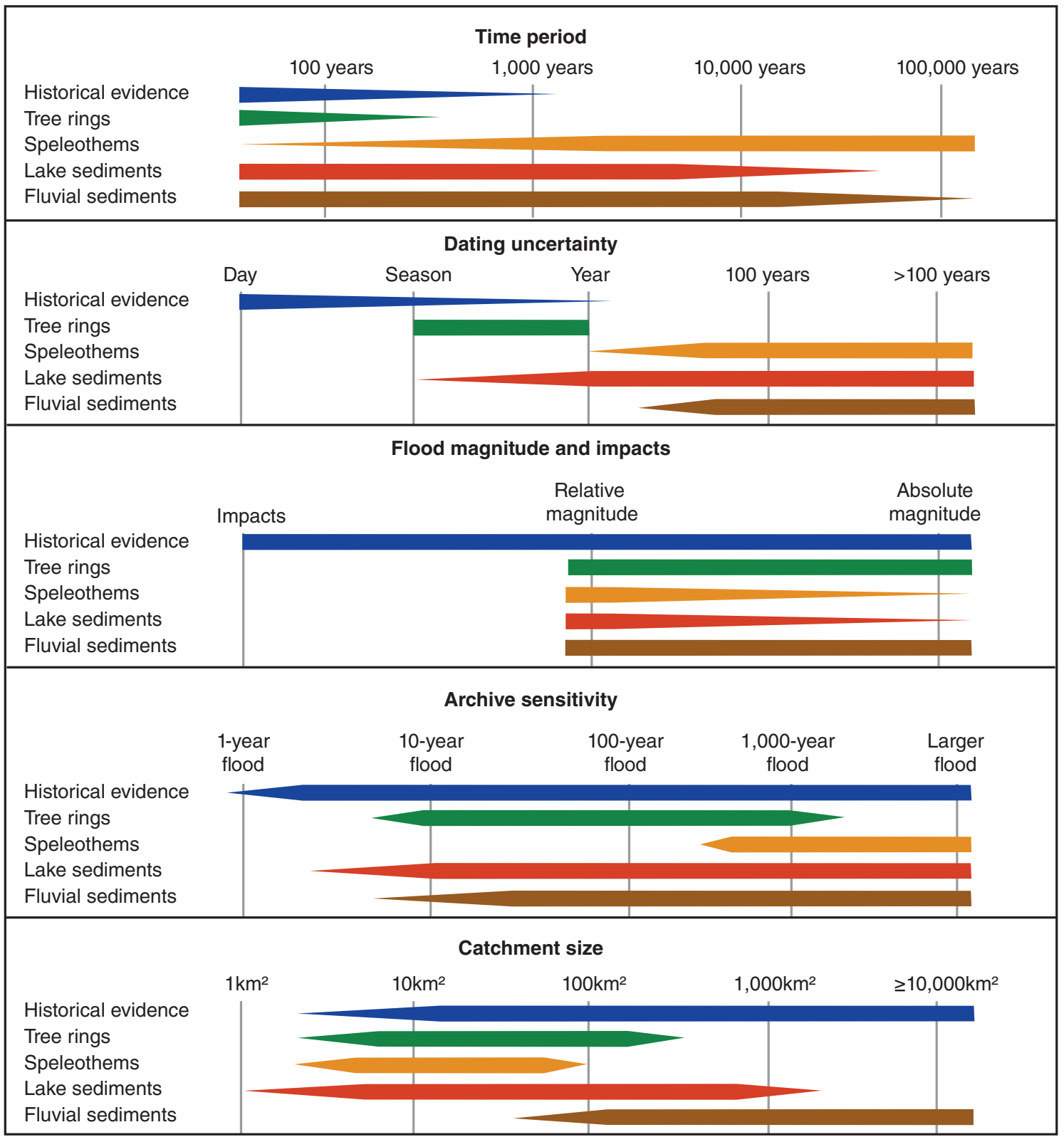

FIGURE 7 Conceptual diagram with the main characteristics of the different flood archives

The chronological length of documentary sources reflects preservation and the presence of recorders (of literate individuals), while geological flood records are mostly limited by technical sampling issues and dating methods.

\subsection{2 | Further data characteristics}

The nature of flood information depends on archive type and applied methods. To further explore the available flood data, key characteristics such as dating uncertainties, potential to reconstruct flood magnitude, archive sensitivity and catchment scale are briefly detailed (Figure 7).

Dating uncertainties in historical records are often minimal as many flood events are typically reported to a specific day, or at worst related to a month or a year. Tree rings permit past floods to be resolved to seasonal or annual scales. Among the geological records, lake sediments and speleothems are sometimes seasonally laminated and may then provide records at the same time scale. However, in most cases, dating uncertainties of geological records mostly depends on the dating methods applied and time period of the records. Generally, geological records covering recent centuries are affected by decadal-scale uncertainties, while records covering millennia are affected by decadal to century-scale uncertainties. A classical way to reduce these uncertainties is then to tie flood deposits to historical flood events that are perfectly dated (Medialdea, Thomsen, Murray, \& Benito, 2014; Wilhelm, Vogel, \& Anselmetti, 2017). 
About half of the data series also contain information about flood magnitudes. Historical documents often offer the richest information as they may fully document flood-related impacts on populations and flood water levels, which can be used to calculate flood discharges through hydraulic reconstructions. The elevation of riverine flood sediments or flood-impacted trees above the river similarly permits an estimate of flood water level and thus, flood discharges. A comparable approach may also be applied to speleothems (Figure 3). Lake sediments do not document water level, instead alternative approaches have been developed to reconstruct relative event magnitude and even in a few cases absolute magnitude.

The frequency and sensitivity at which floods are recorded varies according to archive type (Figure 7). Historical sources may be particularly rich, as flood events can be recorded at a high frequency (subannual), with high levels of detail documented for the most severe and catastrophic events. Trees growing directly next to rivers are more commonly struck by floodrafted debris and may not survive extreme floods, while those farther away from the main channel (but still located within the flood zone) are more likely to survive and record high-magnitude events. Depending on their locations, speleothems have the potential to record frequent floods, but their dating may be complicated by the relative abundance of detrital material in the slow-growing matrix. Hence, paleoflood records from speleothems classically focus on less frequent events (larger than 100 -year floods). In other geological records such as lake sediments, the frequency of recorded floods will be site-specific, mostly depending on the sediment availability in the catchment area. For fluvial sedimentary records the frequency of recording floods mainly depends on the chosen site for investigation (e.g., its proximity and elevation above normal floods levels), as most regular (annual) events can already produce sedimentary evidences at places near to the river, while the higher and distal parts of floodplains and valleys are inundated less frequently.

Historical documents often record the most severe and catastrophic floods that impacted communities adjacent to rivers. While the longest series often reflect the greater presence of literate individuals in urban areas, occasionally smaller sites may also include accounts, as such accounts can be found across the full range of catchment sizes, but are most common in settlements adjacent to large rivers. Similarly, the study of fluvial sediments has often been undertaken to provide information about past events that could be catastrophic if they happen again. By contrast, records based on tree rings, speleothems or lake sediments mostly provide information about floods that occurred in relatively small catchment areas, in part reflecting the location of suitable sites (e.g., caves or lakes).

\section{2 | Toward a more accurate assessment of flood hazard and risk}

\subsection{1 | Risk related to extreme flooding}

Recent natural disasters exemplify what may be termed "Black Swans" (Taleb, 2010), seemingly surprising, extreme-impact events that exceed expected possibilities. One may argues that extreme-event science should place major emphasis on extremes, instead of extrapolating from large populations of common phenomena, as it is conventionally undertaken in the current flood frequency paradigm (Taleb, 2010). The latter, by concentrating on the ordinary and the "normal" often relegates extremes to "outlier" status, and instead focuses attention on statistical analyses of the large samples available for ordinary cases. Both documentary and natural archives provide a greater evidence base of extreme events for inclusion in frequency analysis, thereby reducing the reliance on relatively short instrumental series. Unfortunately, reliance upon conventional measurements (rarely more than several decades for flood events) means that the range of possible events is almost always poorly constrained. Even in those rare cases when an extreme appears in a flood record, its relegation to "outlier" status often leads to minimization of its importance. Conventional practice must therefore make assumptions about the population of observed and potential flood events, and consequently the probability for extreme events. Uncertainties often get expressed in an aleatory sense, relying on assumptions about randomness, informed only by the statistical record of the small common floods, and thereby ignoring the epistemic uncertainty associated with lack of knowledge concerning extremes. In considering the 2011 Japanese tsunami the immense economic loss from that event, arguably the greatest for any natural disaster in human history, was caused by the refusal/failure of responsible authorities to recognize that a geologically documented event of similar magnitude actually occurred about 1,000 years earlier (Minouri, Imarura, Sugawara, Kono, \& Iwashita, 2001). This ignored the certainty that what has actually happened can indeed occur again, something that can only be realized through an approach that incorporates information on extreme flooding that extends over time scales of hundreds and thousands of years.

Natural, archival and instrumental datasets can be brought together for statistical analysis, providing a clearer perspective on extreme event frequency. Nevertheless, few countries legally require paleoflood and/or historical flood risk analyses to be undertaken prior to new developments (e.g., building or infrastructure). The rare exceptions in Europe being Spain and the United Kingdom, where a review of natural and archival sources is legally required (Kjeldsen et al., 2014). Though temporally more limited than the millennial records of paleoflood data (Figure 7), historical documentary archives provide detailed accounts of impacts (e.g., costs, damage, loss of life), as well as information on how communities responded to, and mitigated for, future events. These historical accounts inform the development and evolution of risk management (Brázdil et al., 2012), by observing how communities evolved in responding to extreme events. The irony is that the common-sense recognition that 
what has actually occurred in the past could happen again has much more potential to provoke engaged and wise public response than the abstract prognostications provided by conventional practice, thereby facilitating greater community engagement, improved public understanding of risk, and better decision making.

\subsection{2 | Flood-frequency analysis}

Flood frequency analysis (FFA) is a classical method in hydrology engineering, widely used for flood hazard mapping and hydraulic infrastructure design. FFA uses statistics to obtain the relationship between flood quantiles and their nonexceedance probability, that is, to quantify the risk that a flood with a given discharge will be reached in a near future. Conventional FFA uses annual maximum flood (AMF) records or more generally "block maxima" if the considered time window is longer or shorter (seasonal) than a year. Typically, FFA from gauge stations involves 10 to 100 years of observations to estimate for example events exceeded with a chance of at least 1 in 100 for hazard mapping, 1 in 1000-5,000 for dam spillway design or even 1 in 10.000 for hazardous flooding in nuclear plants. Historical and paleoflood data can increase the information length and include the information of extreme events (Baker, 2008), often missed in gauge records. The combination of systematic (gauge) and nonsystematic (historical and paleoflood) data from the statistical point of view results in a blend of categorical data with discrete variables measured continuously. The categorical data in extreme flow analysis are known as peak over a threshold (POT data), while annual series of maximum daily flows are known as AMF. The inclusion of nonsystematic data in FFA consider historical and palaeoflood data as censored data, which means that for a given event to be registered, it must exceed a certain value or threshold (Leese, 1973). Thus, all floods that exceed a certain magnitude or threshold $\left(X_{t}\right)$ in $M$ years are known and, therefore, the remaining years in the series were below that discharge threshold (Frances, 2004; Stedinger \& Cohn, 1986). Recent works have seen the development and inclusion of uncertainty bounds around return frequency estimation from historically augmented series (Frances, 2004; Macdonald et al., 2014).

Although paleoflood data provide a more rational assessment of extreme events, very low-probability floods could be still missed due to lack of conservation of the palaeoevidence. To address this point, several studies have been focused on indicators of nonflooded surfaces (elevation inferred not to have been inundated for a time period) to define nonexceedance discharge thresholds (England, Godaire, Klinger, Bauer, \& Julien, 2010; Levish, Ostenaa, \& O'Connell, 1996). Stable alluvial terraces have been also used as "paleohydrologic bound" or upper limits of flooding over a time interval established by geochronological means (England et al., 2010; Levish et al., 1996). Evidence for surface stability typically includes pedogenetic alterations, volcanic tephra, desert varnish disruption or other features readily affected by flooding. Such bounds can significantly constrain the tail of flood-frequency distributions and, in many cases, lead to more robust frequency and magnitude estimates of rare and large floods (O'Connell, Ostenaa, Levish, \& Klinger, 2002). However, a nonexceedance bound does not imply that the estimated peak discharge has ever occurred or that such a flood is even physically possible (Levish, 2002).

The main assumption of FFA is that the random variable must be independent and identically distributed (stationary, iid) through time. Natural systems oscillate within an unchanging envelope of variability, resulting in nonstationary hydrological responses (Milly et al., 2008). The temporal changes (nonstationarity) are often related to natural, low frequency variations of the climate system or to human impacts on the catchment hydrological parameters, such as land use (Benito et al., 2004; Frances, 2004; Redmond, Enzel, House, \& Biondi, 2002). ${ }^{11,161,169}$ Data used in conventional FFA should comply with the iid assumption, specifically related to stationarity. To this end, a stationarity test for censored series has been developed (Lang, Ouarda, \& Bobée, 1999), which has been used on historical (Figure 8(a); Barriendos et al., 2003; Naulet et al., 2005), fluvial (Figure 8(b); Benito et al., 2011) and lake records (Corella et al., 2016). For statistical modeling, FFA uses a combination of a cumulative distribution function (e.g., Gumbel, LP3, GEV, etc.) and a parameter estimation method (Frances, 2004; Ouarda, Rasmussen, Bobee, \& Bernier, 1998). The statistical methods used to include censored data in the continuous systematic records are maximum likelihood estimators (Leese, 1973; Stedinger \& Cohn, 1986), the method of expected moments (Cohn \& Stedinger, 1987; England, Salas, \& Jarrett, 2003) and Bayesian methods (Gaume, 2018; Kuczera, 1999; O'Connell, 2005; O'Connell et al., 2002). Many examples can be given on the application of FFA using both gauged and paleoflood records (Denlinger, O'Connell, \& House, 2002; Thorndycraft et al., 2005).

Regional flood frequency assessment (RFFA) has been also developed and applied to merge nonsystematic and systematic records by flow-index regionalization. This approach is based on the distribution of flow discharge from different catchments of a homogenous region, which is often tested using the "Hosking and Wallis" algorithm (Hosking \& Wallis, 1987). The RFFA has been used to merge systematic data and historical (Gaál, Szolgay, Kohnová, Hlavčová, \& Viglione, 2010; Gaume et al., 2010), fluvial (Lam, Thompson, \& Croke, 2016), and tree-ring (Ballesteros-Cánovas et al., 2017; Figure 8(c)) data. RFFA enables more flexibility since it allows including paleofloods computed far from the reach river where the gauge station is located, which may maximize the use of paleoflood data in a certain region.

The application of FFA and RFFA under nonstationary conditions has been recently developed. To this end, Generalized Additive Models for Location, Scale and Shape parameters (GAMLSS) have been used to describe the temporal variation of 

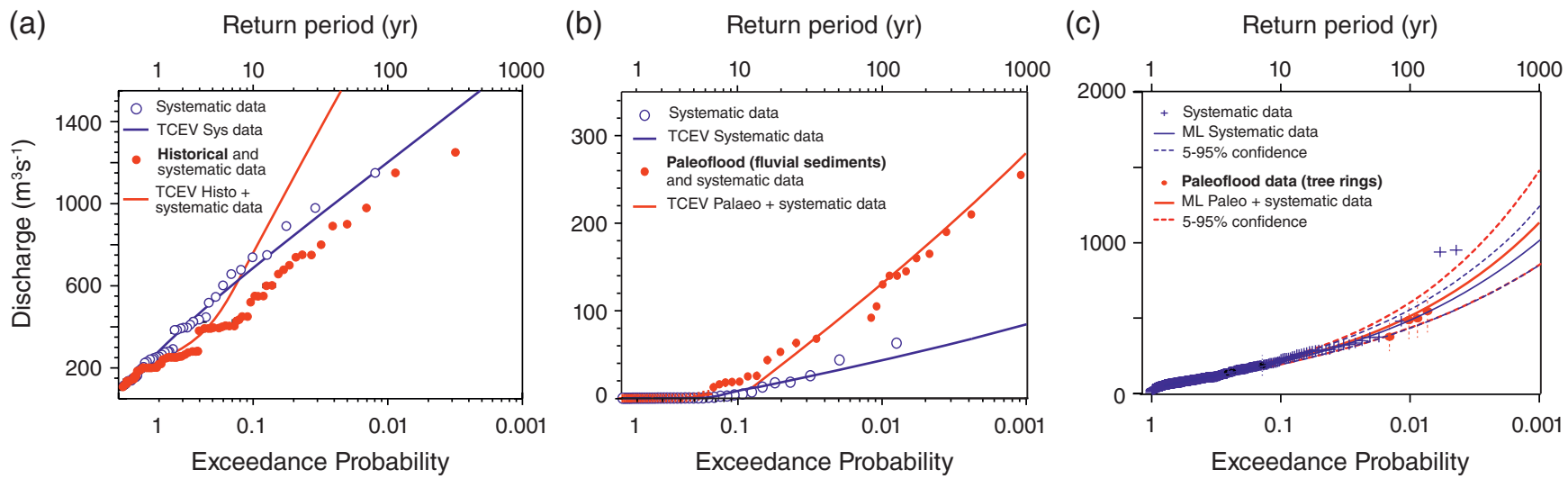

FIGURE 8 Examples of flood frequency analysis using systematic (gauge) data only and systematic data with historical (a; Machado et al., 2015), fluvial (b; Harden et al., 2015), or tree ring data (c; Ballesteros-Cánovas et al., 2017). The distribution functions fitted to these flood datasets are two component extreme value (TCEV) and maximum likelihood (ML). The inclusion of historical and paleoflood data modifies the specific return periods and may reduce the uncertainty in discharge for events with large return periods

statistical parameters (mean, variance) in probability distribution functions (Gumbel, Lognormal, Weibull, Gamma; Rigby \& Stasinopoulos, 2005). In nonstationary series statistical parameters may show changes that can be modeled (as a trend or smooth function) using time (Villarini et al., 2009) or related to a hydro-climatic index (e.g., Pacific Decadal Oscillation, North Atlantic Oscillation, Arctic Oscillation) as covariates (Lopez \& Frances, 2013). Nonstationary models may be implemented with categorical paleoflood data, once the driving covariate on parameter change is established (Machado et al., 2015). These changes on annual probability during past periods may be indicative for flood hazard change under the ongoing climate change.

\subsection{3 | Climate - Flood relationships}

A key feature of historical and palaeoflood records is the variability in flood recurrence at centennial-millennial timescales. However, such variations seem difficult to derive from gauge data as a result of their relative shortness in length. This high variability in flood recurrence was described in terms of "flood-rich" and "flood-poor" periods, which suggests a nonstationary model of flood occurrence (Merz et al., 2014; Mudelsee, Börngen, Tetzlaff, \& Grünewald, 2003). This nonstationarity is often related to natural, low-frequency variations of the climate system and/or to human impacts on the catchment hydrological and erosion processes, such as land use (Arnaud et al., 2016; Benito et al., 2004). Disentangling these two factors and their possible interplays through time is a complex issue, requiring a number of different approaches (Jones et al., 2010; Mudelsee, Börngen, Tetzlaff, \& Grünewald, 2004). However, once the role of these factors is well constrained and the entire chain of recording mechanisms is captured, then historical and palaeoflood data are highly valuable records to better understand the links between climate variability and flooding on centennial-millennial timescales. Owing to the shortness and inherent uncertainties in the records (measurement or reconstruction), it is mandatory to employ adequate statistical data analytical methods. These deliver accurate estimations of the nonstationary flood occurrence model and form the basis for making robust attributions about climate and human influences (Merz, Vorogushyn, Uhlemann, Delgado, \& Hundecha, 2012).

A parametric estimation model for Peak Over Threshold (POT) data is the Generalized Pareto distribution with time dependences in the three parameters, location, scale, and shape (Coles, 2001). However, due to the increased numbers of parameters to be estimated to describe the nonstationarity, estimation may become a technical problem, especially if the shape parameter is allowed to be time-dependent (Mudelsee, 2014). A further deficit of this approach is that the functional form of the nonstationarities is parametrically prescribed, which may in practice restrict its usefulness, particularly for long series. The same deficit is shared by the GEV distribution with time-dependent parameters for block extremes (Coles, 2001). A more flexible, nonparametric estimation model for extreme values is the Poisson point process, which has as estimation target the time-dependent occurrence rate (number of events per time unit). The occurrence rate can be estimated by means of a kernel technique, and a confidence band can be constructed by means of bootstrap resampling (Figure 9; Cowling, Hall, \& Phillips, 1996). For mathematical details, such as boundary bias correction or studentization (Mudelsee, 2014). Statistical tests of the null hypothesis "constant occurrence rate" (i.e., stationarity) serve to assess the significance of the estimation result (i.e.,the trends in occurrence rate). A widely used test employs the logistic model (Frei \& Schär, 2001) or even simpler models (Cox \& Lewis, 1966). A method not recommended for detecting nonstationarities in the extremal part is the trend test after Mann and Kendall, since this is a test for changes in the mean, not the extremes. Test performances have been compared using Monte Carlo simulations (Mudelsee, 2014). 


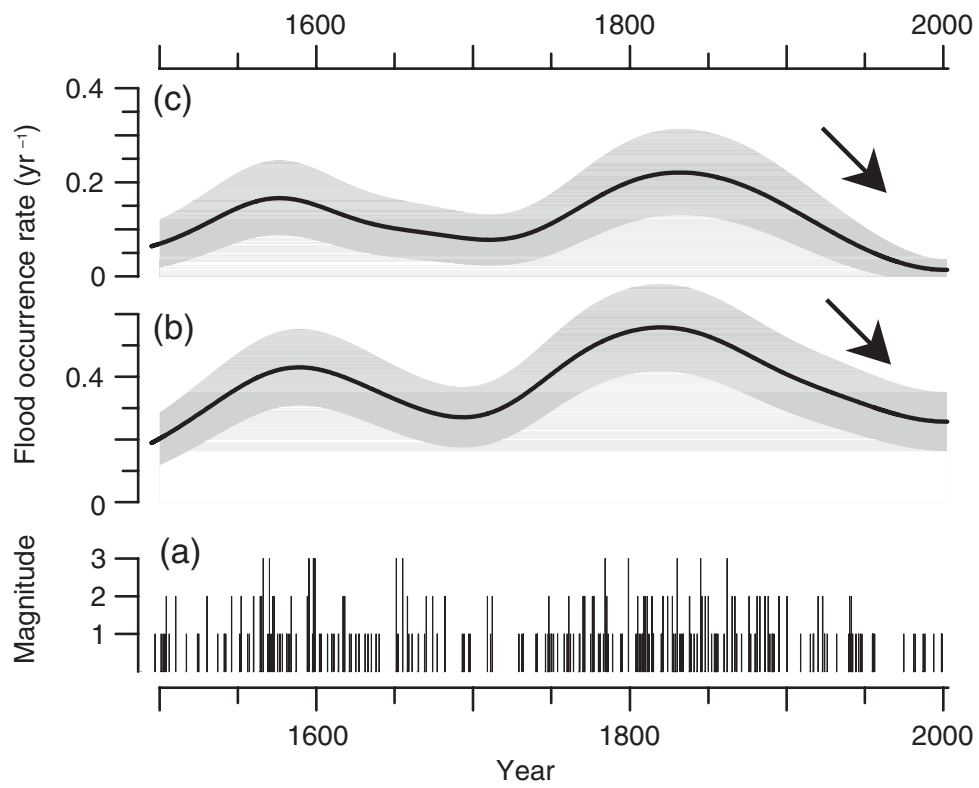

FIGURE 9 Historical winter floods of the Elbe river (a) and occurrence rates with 90\% confidence band for all floods (magnitude classes 1 to 3; b) and heavy floods only (magnitude classes 2 to 3 ; c). Arrows highlight the downward trends obtained from the statistical test after Cox and Lewis (significant at the one sided $90 \%$ level) for trend in the flood occurrence rate for the instrumental period (1850-2002). (Reprinted with permission from Mudelsee et al. (2003). Copyright 2003 Nature Publishing Group)

Changes in flood frequency over multi-millennial scales have been tied for instance to climatic regimes (glacial vs. interglacial climates; Spötl, Boch, \& Wolf, 2011), while changes occurring over multi-centennial scales have been linked to changes in atmospheric circulation modes such as the El Niño-Southern Oscillation (Denniston et al., 2015; Munoz \& Dee, 2017), the North Atlantic Oscillation (Foulds \& Macklin, 2015; Mudelsee et al., 2004; Schulte et al., 2015; Toonen, Foulds, Macklin, \& Lewin, 2017; Wilhelm et al., 2012; Wirth et al., 2013), or the Western Mediterranean Oscillation (Corella et al., 2016). Identification of such connections provide a base for potential improvement of hydrological projections, mainly if the forcing are predictable or slowly evolving (Merz et al., 2014). In between these timescales, the solar activity has also been proposed to explain changes in flood frequency (Benito, Brázdil, et al., 2015; Corella et al., 2014; Czymzik et al., 2010; Macdonald \& Sangster, 2017; Sabatier et al., 2017; Wilhelm et al., 2012). Better understand these relationships between climate and flooding is important in the context of the ongoing climate change, as the warming is expected to impact magnitude, frequency and timing of river floods.

\section{4 | CONCLUSION}

Societies are currently under increasing threat from riverine floods, which are among the most destructive of natural hazards. Accurate flood hazard and risk assessment are therefore crucial for the sustainable development of societies worldwide. However, they are limited by the paucity of hydrological measurements. Historical and natural archives offer a valuable opportunity to extent current flood information in time and space and, moreover, offer the only insight into truly extreme events. Hence, historical and paleoflood data has considerable, but underutilized potential, to improve flood hazard assessments and, thereby, flood management and mitigation plans.

The development of this "field evidence" approach to various archives makes its application possible in various settings and ungauged basins. This also results in a greater diversity of reconstructed flood information related to the specificity of each archive to record flood occurrence and magnitude. Moreover, the application of this approach by an increasing number of disciplines and/or communities provides an increasing dataset of global historical and paleoflood series. A challenge for the coming years is to gather, promote and share all these datasets to favor their use and integration in flood hazard assessments. For instance, increasingly combinations of historical and natural datasets can be brought together with instrumental data for statistical analysis, permitting analysis of noncontinuous datasets to better understand extreme event frequency, in so doing greater confidence can be placed in past event magnitudes. In recognizing other sources of information beyond conventional records, historical and paleoflood datasets often contain evidence of notable rare extremes, which do not justify the all-toocommon assumption that information concerning extremes does not exist. Where such events exist within conventional datasets natural and archival sources can dispel claims of uniqueness, unparalleled magnitude or severity that are often associated with such extreme events. In recognizing and engaging with natural and archival sources, greater understanding can be 
achieved, communities engaged, facilitating greater and improved public understanding of the risks presented as well as improved decision making.

\section{ACKNOWLEDGMENTS}

This publication is a contribution to the Past Global Changes (PAGES) Floods Working Group. PAGES is supported by the US National Science Foundation and the Swiss Academy of Sciences. In addition, the publication has been inspired by the "Cross-community workshop on past flood variability" of the PAGES Floods Working Group that held in Grenoble, France, June 27-30, 2016. The meeting has been generously supported by Past Global Changes, Labex OSUG@2020 (Investissements d'avenir - ANR10 LABX56), European Geosciences Union, Grenoble-INP and Université Grenoble Alpes. The worldwide overview of historical and paleoflood records shown in Figure 6 was made possible thanks to many contributors that we warmly thanked. Further contributions are still warmly welcome as they will enable to update the interactive metadatabase (http://pastglobalchanges.org/ini/wg/floods/wp1/data). The authors are very grateful to the Editor Stuart Lane for the invitation to submit this manuscript and to Eric Gaume and the anonymous reviewer for their constructive comments.

\section{CONFLICT OF INTEREST}

The authors have declared no conflicts of interest for this article.

\section{RELATED WIRES ARTICLES}

Floods and societies: the spatial distribution of water-related disaster risk and its dynamics

Flood frequency analysis: The Bayesian choice

\section{ORCID}

Bruno Wilhelm (10) http://orcid.org/0000-0002-0555-1915

\section{FURTHER READING}

For general information on the regional to global knowledge on flood evolution in the context of the ongoing climate change, the reader is encouraged to have a look to the IPCC special report (2012). on "Managing the Risks of Extreme Events and Disasters to Advance Climate Change Adaptation" freely available here: https:// www.ipcc.ch/pdf/special-reports/srex/SREX_Full_Report.pdf

For more information related to the development and use of the paleoflood approaches in mountainous areas, the reader is directed to the book 'Dating Torrential Processes on Fans and Cones - Methods and Their Application for Hazard and Risk Assessment'published in a special issue of Advance in Global Change Research. Please see: http://www.springer.com/us/book/9789400743359

To know more about the Paleoflood Hydrology historically based on fluvial sediments, the reader can be interested by 'House, P. K., Webb, R. H., Baker, V. R., \& Levish, D. (Eds.), (2002). Ancient floods, modern hazards: Principles and applications of paleoflood hydrology. Water science and application, vol. 5. American Geophysical Union. 385 pp.

\section{REFERENCES}

Amann, B., Sönke, S., \& Grosjean, M. (2015). A millennial-long record of warm season precipitation and flood frequency for the Northwestern Alps inferred from varved lake sediments: Implications for the future. Quaternary Science Reviews, 115, 89-100. https://doi.org/10.1016/j.quascirev.2015.03.002

Aon Benfield. (2016). 2016 Annual Global Climate and Catastrophe Report, 75 p. Retrieved from http://thoughtleadership.aonbenfield.com/ Documents/20170117-ab-if-annual-climate-catastrophe-report.pdf

Arbellay, E., Fonti, P., \& Stoffel, M. (2012). Duration and extension of anatomical changes in wood structure after cambial injury. Journal of Experimental Botany, 63, 3271-3277. https://doi.org/10.1093/jxb/ers050

Arnaud, F., Poulenard, J., Giguet-Covex, C., Wilhelm, B., Révillon, S., Jenny, J. P., ... Sabatier, P. (2016). Erosion under climate and human pressures: An alpine lake sediment perspective. Quaternary Science Reviews, 152, 1-18. https://doi.org/10.1016/j.quascirev.2016.09.018

Atkinson, T. C., Lawson, T. J., Smart, P. L., Harmon, R. S., \& Hess, J. W. (1986). New data on speleothem deposition and palaeoclimate in Britain over the last forty thousand years. Journal of Quaternary Science, 1, 67-72. https://doi.org/10.1002/jqs.3390010108

Baker, V. R. (2008). Paleoflood hydrology: Origin, progress, prospects. Geomorphology, 101(1), 1-13. https://doi.org/10.1016/j.geomorph.2008.05.016

Ballesteros-Cánovas, J. A., Stoffel, M., Bodoque, J. M., Bollschweiler, M., Hitz, O., \& Díez-Herrero, A. (2010). Changes in wood anatomy in tree rings of Pinus pinaster Ait. following wounding by flash floods. Tree-Ring Bulletin, 66(2), 93-103. https://doi.org/10.3959/2009-4.1

Ballesteros-Cánovas, J. A., Eguibar, M., Bodoque, J. M., Díez-Herrero, A., Stoffel, M., \& Gutiérrez-Pérez, I. (2011). Estimating flash flood discharge in an ungauged mountain catchment with 2D hydraulic models and dendrogeomorphic paleostage indicators. Hydrological Processes, 25, 970-979. https://doi.org/10.1002/hyp. 7888

Ballesteros-Cánovas, J. A., Márquez-Peñaranda, J. F., Sánchez-Silva, M., Díez-Herrero, A., Ruiz-Villanueva, V., Bodoque, J. M., \& Stoffel, M. (2014). Can tilted trees be used for palaeoflood discharge estimation? Journal of Hydrology, 529(2), 480-489. https://doi.org/10.1016/j.jhydrol.2014.10.026

Ballesteros-Cánovas, J. A., Stoffel, M., St George, S., \& Hirschboeck, K. (2015). A review of flood records from tree rings. Progress in Physical Geography, 39(6), 794-816. https://doi.org/10.1177/0309133315608758 
Ballesteros-Cánovas, J. B., Trappmann, D., Shekhar, M., Bhattacharyya, A., \& Stoffel, M. (2017). Regional flood-frequency reconstruction for Kullu district, Western Indian Himalayas. Journal of Hydrology, 546, 140-149. https://doi.org/10.1016/j.jhydro1.2016.12.059

Barriendos, M., Cœur, D., Lang, M., Llasat, M. C., Naulet, R., Lemaitre, F., \& Barrera, A. (2003). Stationarity analysis of historical flood series in France and Spain (14th-20th centuries). Natural Hazards and Earth System Sciences, 3, 583-592.

Barriendos, M., \& Rodrigo, F. S. (2006). Study of historical flood events on Spanish rivers using documentary data. Hydrological Sciences Journal, 51, 765-783. https://doi.org/10.1623/hysj.51.5.765

Bättig, G., \& Wildberger, A. (2007). Comparison de la crue d'août 2005 dans le Hölloch avec les crues antérieures. Stalactite, 57, 26-34.

Belli, R., Borsato, A., Frisia, S., Drysdale, R., Maas, R., \& Greig, A. (2017). Investigating the hydrological significance of stalagmite chemical (Mg, Sr) using Sr isotope and particulate element records across the Late Glacial-to-Holocene transition. Geochimica et Cosmochimica Acta, 197, 247-263. https://doi.org/10.1016/j.gca. 2016.10.024

Benito, G., Lang, M., Barriendos, M., Llasat, M. C., Francés, F., Ouarda, T., ... Bobée, B. (2004). Use of systematic, palaeoflood and historical data for the improvement of flood risk estimation. Review of scientific methods. Natural Hazards, 31(3), 623-643.

Benito, G., Ouarda, T. B. M. J., \& Bárdossy, A. (2005). Applications of palaeoflood hydrology and historical data in flood risk analysis. Journal of Hydrology, 313, 1-2. https://doi.org/10.1016/j.jhydrol.2005.02.001

Benito, G., Rico, M., Sánchez-Moya, Y., Sopeña, A., Thorndycraft, V. R., \& Barriendos, M. (2010). The impact of late Holocene climatic variability and land use change on the flood hydrology of the Guadalentín River, southeast Spain. Global and Planetary Change, 70(1), 53-63.

Benito, G., Botero, B. A., Thorndycraft, V. R., Rico, M. T., Sánchez-Moya, Y., Sopeña, A., ... Dahan, O. (2011). Rainfall-runoff modelling and palaeoflood hydrology applied to reconstruct centennial scale records of flooding and aquifer recharge in ungauged ephemeral rivers. Hydrology and Earth System Sciences, 15, $1185-1196$.

Benito, G., Brázdil, R., Herget, J., \& Machado, M. J. (2015). Quantitative historical hydrology in Europe. Hydrology and Earth System Sciences, 19, 3517-3539. https://doi.org/10.5194/hess-19-3517-2015

Benito, G., Macklin, M. G., Panin, A., Rossato, S., Fontana, A., Jones, A. F., ... Zielhofer, C. (2015). Recurring flood distribution patterns related to short-term Holocene climatic variability. Scientific Reports, 5, 16398. https://doi.org/10.1038/srep16398

Blöschl, G., Nester, T., Komma, J., Parajka, J., \& Perdigão, R. A. P. (2013). The June 2013 flood in the Upper Danube Basin, and comparisons with the 2002, 1954 and 1899 floods. Hydrology and Earth System Sciences, 17(12), 5197-5212.

Blöschl, G., Hall, J. L., Parajka, J., Perdigao, R. A. P., Merz, B., Arheimer, B., ... Živković, N. (2017). Changing climate shifts timing of European floods. Science, 2017(357), 588-590. https://doi.org/10.1126/science.aan2506

Boch, R., \& Spötl, C. (2011). Reconstructing palaeoprecipitation from an active cave flowstone. Journal of Quaternary Science, $26,675-687$.

Böhm, O., \& Wetzel, K.-F. (2006). Flood history of the Danube tributaries Lech and Isar in the Alpine foreland of Germany. Hydrological Sciences Journal, 51, 784-798. https://doi.org/10.1623/hysj.51.5.784

Brázdil, R., Kundzewicz, Z. W., \& Benito, G. (2006). Historical hydrology for studying flood risk in Europe. Hydrological Sciences Journal, 51, 739-764. https://doi. org/10.1623/hysj.51.5.739

Brázdil, R., Kundzewicz, Z. W., Benito, G., Demarée, G., Macdonald, N., \& Roald, L. A. (2012). Historical floods in Europe in the past millennium. In Changes in flood risk in Europe (pp. 121-166. IAHS Special Publication 10). Wallingford, England: Zbigniew W. Kundzewicz. isbn:978-1-907161-28-5.

Brown, A. G., Cooper, L., Salisbury, C. R., \& Smith, D. N. (2001). Late Holocene channel changes of the middle Trent: Channel response to a thousand year flood record. Geomorphology, 39, 69-82.

Brunck, H., Sirocko, F., \& Albert, J. (2016). The ELSA-Flood-Stack: A reconstruction from the laminated sediments of Eifel maar structures during the last 60000 years. Global and Planetary Change, 142, 136-146.

Cohn, T. A., \& Stedinger, J. R. (1987). Use of Historical Information in a Maximum Likelihood Framework. Journal of Hydrology, 96, 215-233.

Coles, S. (2001). An introduction to statistical modeling of extreme values. London, England: Springer.

Corella, J. P., Benito, G., Rodriguez-Lloveras, X., Brauer, A., \& Valero-Garcés, B. L. (2014). Annually-resolved lake record of extreme hydro-meteorological events since AD 1347 in NE Iberian Peninsula. Quaternary Science Reviews, 93, 77-90.

Corella, J., Valero-Garcés, B., Vicente-Serrano, S., Brauer, A., \& Benito, G. (2016). Three millennia of heavy rainfalls in Western Mediterranean: Frequency, seasonality and atmospheric drivers. Scientific Reports, 6, 38206.

Costa, J. E. (1978). Holocene stratigraphy in flood frequency analysis. Water Resources Research, 14(4), 626-632.

Cowling, A., Hall, P., \& Phillips, M. J. (1996). Bootstrap confidence regions for the intensity of a Poisson point process. Journal of the American Statistical Association, $91,1516-1524$.

Cox, D. R., \& Lewis, P. A. W. (1966). The statistical analysis of series of events. London, England: Methuen.

CRED (UNISDR). (2015). The human cost of natural disasters: A global perspective, 58 pp. Retrieved from http://cred.be/sites/default/files/The_Human_Cost_of_ Natural_Disasters_CRED.pdf

Czymzik, M., Dulski, P., Plessen, B., von Grafenstein, U., Naumann, R., \& Brauer, A. (2010). A 450 year record of spring-summer flood layers in annually laminated sediments from Lake Ammersee (southern Germany). Water Resources Research, 46, W11528.

Czymzik, M., Brauer, A., Dulski, P., Plessen, B., Naumann, R., von Grafenstein U., \& Scheffler, R. (2013). Orbital and solar forcing of shifts in Mid-to Late Holocene flood intensity from varved sediments of pre-alpine Lake Ammersee (southern Germany). Quaternary Science Reviews, 61, 96-110.

Dasgupta, S., Saar, M. O., Edwards, R. L., Shen, C.-C., Cheng, H., \& Alexander, E. C. (2010). Three thousand years of extreme rainfall events recorded in stalagmites from Spring Valley Caverns, Minnesota. Earth and Planetary Science Letters, 300, 46-54.

Demarée, G. R. (2006). The catastrophic floods of February 1784 in and around Belgium—A Little Ice Age event of frost, snow, river ice and floods. Hydrological Sciences Journal, 51, 878-898. https://doi.org/10.1623/hysj.51.5.878

Denlinger, R. P., O'Connell, D. R. H., \& House, P. K. (Eds.) (2002). Robust determination of stage and discharge: An example from an extreme flood on the Verde River, Arizona. In Ancient floods, modern hazards: Principles and applications of paleoflood hydrology Water science and application series (Vol. 5, pp. 127-146). Washington, DC: American Geophysical Union.

Denniston, R. F., Villarini, G., Gonzales, A. N., Wyrwoll, K. H., Polyak, V. J., Ummenhofer, C. C., ... Cugley, J. (2015). Extreme rainfall activity in the Australian tropics reflects changes in the El Nino/southern oscillation over the last two millennia. Proceedings of the National Academy of Sciences, $112,4576-4581$.

Denniston, R. F., \& Luetscher, M. (2017). Speleothems as high-resolution paleoflood archives. Quaternary Science Reviews, 170, 1-13.

Dorale, J. A., Edwards, R. L., Alexander, E. C., Shen, C. C., Richards, D. A., \& Cheng, H. (2004). Uranium-series dating of speleothems: Current techniques, limits, \& applications. In I. D. Sasowsky \& J. Mylroie (Eds.), Studies of cave sediments (pp. 177-197). Boston, MA: Springer.

Egginton, P. A., \& Day, T. J. (1977). Dendrochronologic investigation of high water events along Hodgson Creek, District of Mackenzie. Geological Survey of Canada, 77(1A), 381-384.

Ely, L. L., Webb, R. H., \& Enzel, Y. (1992). Accuracy of post-bomb 137Cs and 14C in dating fluvial deposits. Quaternary Research, 38(2), $196-204$.

England, J. F. J., Salas, J. D., \& Jarrett, R. D. (2003). Comparisons of two moments-based estimators that utilize historical and paleoflood data for the log-Pearson Type III distribution. Water Resources Research, 39(9), 5-1-5-16. 
England, J., Godaire, J., Klinger, R., Bauer, T., \& Julien, P. (2010). Paleohydrologic bounds and extreme flood frequency of the Upper Arkansas River, Colorado, USA. Geomorphology, 124(1), 1-16.

Finné, M., Bar-Matthews, M., Holmgren, K., Sundqvist, H. S., Liakopoulos, I., \& Zhang, Q. (2014). Speleothem evidence for late Holocene climate variability and floods in Southern Greece. Quaternary Research, 81, 213-227.

Forel, F. A. (1885). Les ravins sous-lacustres des fleuves glaciaires. Comptes Rendus de l'Académie des Sciences de Paris, 101(16), 725-728.

Foulds, S. A., \& Macklin, M. G. (2015). A hydrogeomorphic assessment of 21st century floods in the UK. Earth Surface Processes and Landforms, 41(2), 256-270. https://doi.org/10.1002/esp.3853

Frances, F. (2004). Flood frequency analysis using systematic and non-systematic information. In G. Benito \& V. R. Thorndycraft (Eds.), Systematic, Paleoflood and historical data for the improvement of flood risk estimation: Methodological guidelines (pp. 55-70). Madrid, Spain: CSIC.

Frei, C., \& Schär, C. (2001). Detection probability of trends in rare events: Theory and application to heavy precipitation in the Alpine region. Journal of Climate, 14, $1568-1584$.

Friedman, J. M., Vincent, K. R., \& Shafroth, P. B. (2005). Dating floodplain sediments using tree-ring response to burial. Earth Surface Processes and Landforms, 30(9), 1077-1.091.

Gaál, L., Szolgay, J., Kohnová, S., Hlavčová, K., \& Viglione, A. (2010). Inclusion of historical information in flood frequency analysis using a Bayesian MCMC technique: A case study for the power dam Orlík, Czech Republic. Contributions to Geophysics and Geodesy, 40(2), 121-147.

Gaume, E., Gaál, L., Viglione, A., Szolgay, J., Kohnová, S., \& Blöschl, G. (2010). Bayesian MCMC approach to regional flood frequency analyses involving extraordinary flood events at ungauged sites. Journal of Hydrology, 394(1), 101-117.

Gaume, E. (2018). Flood frequency analysis: The Bayesian choice. WIREs Water, 5(4), e1290. https://doi.org/10.1002/wat2.1290

Gázquez, F., Calaforra, J. M., Forti, P., Stoll, H., Ghaleb, B., \& Delgado-Huertas, A. (2014). Paleoflood events recorded in speleothems in caves. Earth Surface Processes and Landforms, 39, 1345-1353.

Gilli, A., Anselmetti, F. S., Glur, L., \& Wirth, S. B. (2013). Lake sediments as archives of recurrence rates and intensities of past flood events. In M. Schneuwly-Bollschweiler, M. Stoffel, \& F. Rudolf-Miklau (Eds.), Dating torrential processes on fans and cones - Methods and their application for hazard and risk assessment Advances in global change research (Vol. 47, pp. 225-242). Heidelberg, Germany: Springer Netherlands.

Giovanoli, F. (1990). Horizontal transport and sedimentation by interflows and turbidity currents in Lake Geneva. In M. M. Tilzer \& C. Serruya (Eds.), Large lakes: Ecological structure and function (pp. 175-195). Berlin, Germany: Springer.

Giguet-Covex, C., Pansu, J., Arnaud, F., Rey, P. J., Griggo, C., Gielly, L., ... Taberlet, P. (2014). Long livestock farming history and human landscape shaping revealed by lake sediment DNA. Nature Communications, 5, 3211. https://doi.org/10.1038/ncomms4211

Glaser, R., Riemann, D., Schönbein, J., Barriendos, M., Brázdil, R., Bertolin, C., ... Himmelsbach, I. (2010). The variability of European floods since AD 1500. Climatic Change, 101, 235-256. https://doi.org/10.1007/s10584-010-9816-7

Glur, L., Wirth, S. B., Buntgen, U., Gilli, A., Haug, G. H., Schär, C., ... Anselmetti, F. S. (2013). Frequent floods in the European Alps coincide with cooler periods of the past 2500 years. Science Reports, 3, 2770. https://doi.org/10.1038/srep02770

González-Lemos, S., Müller, W., Pisonero, J., Cheng, H., Edwards, R. L., \& Stoll, H. M. (2015). Holocene flood frequency reconstruction from speleothems in northern Spain. Quaternary Science Reviews, 127, 129-140.

Gottesfeld, A. S., \& Johnson Gottesfeld, L. M. (1990). Floodplain dynamics of a wandering river, dendrochronology of the Morice River, British Columbia, Canada. Geomorphology, 3, 159-179.

Gottesfeld, A. S. (1996). British Columbia flood scars: Maximum flood-stage indicator. Geomorphology, 14, 319-325.

Gradzinski, M., Hercman, H., Nowak, M., \& Bella, P. (2007). Age of black coloured laminae within speleothems from Domica cave and its significance for dating prehistoric human settlement. Geochronometria, 28, 39-45.

Greenbaum, N., Schwartz, U., Benito, G., Porat, N., Cloete, G. C., \& Enzel, Y. (2014). Paleohydrology of extraordinary floods along the Swakop River, Namib Desert and paleoclimate implications. Quaternary Science Reviews, 103, 153-169.

Grodek, T., Benito, G., Botero, B. A., Jacoby, Y., Porat, N., Haviv, I., ... Enzel, Y. (2013). The last millennium largest floods in the hyperarid Kuiseb River basin, Namib Desert. Journal of Quaternary Science, 28(3), 258-270.

Hall, J., Arheimer, B., Borga, M., Brázdil, R., Claps, P., Kiss, A., et al. (2014). Understanding flood regime changes in Europe: A state-of-the-art assessment. Hydrology and Earth System Sciences, 18, 2735-2772. https://doi.org/10.5194/hess-18-2735-2014

Harden, T. M., Macklin, M. G., \& Baker, V. R. (2010). Holocene flood histories in south-western USA. Earth Surface Processes and Landforms, $35(6), 707-716$.

Harden, T. M., O'Connor, J. E., \& Driscoll, D. G. (2015). Late Holocene flood probabilities in the Black Hills, South Dakota with emphasis on the Medieval Climate Anomaly. Catena, 130, 62-68.

Harrison, S. S., \& Reid, J. R. (1967). A flood-frequency graph based on tree-scar data. Proceedings of the North Dakota Academy of Science, $21,23-33$.

Helly, E. J., \& LaMarche, V. C., Jr. (1973). Historic flood information for northern California stream from geological and botanical evidence. Geology Survey Professional Paper, 485, 1-16.

Herget, J., \& Meurs, H. (2010). Reconstructing peak discharges for historic flood levels in the city of Cologne, Germany. Global and Planetary Change, 70, $108-116$. https://doi.org/10.1016/j.gloplacha.2009.11.011

Himmelsbach, I., Glaser, R., Schoenbein, J., Riemann, D., \& Martin, B. (2015). Reconstruction of flood events based on documentary data and transnational flood risk analysis of the Upper Rhine and its French and German tributaries since AD 1480. Hydrology and Earth System Sciences, 19, 4149-4164. https://doi.org/10.5194/ hess-19-4149-2015

Hosking, J. R. M., \& Wallis, J. R. (1987). Parameter and quantile estimation for the generalized pareto distribution. Technometrics, 29(3), 339-349.

Jacobeit, J., Glaser, R., Luterbacher, J., \& Wanner, H. (2003). Links between flood events in central Europe since AD 1500 and large-scale atmospheric circulation modes. Geophysical Research Letters, 30, 21.1-21.4. https://doi.org/10.1029/2002GL016433

Jahns, R. H. (1947). Geologic features of the Connecticut Valley, Massachusetts as related to recent floods. U.S. Geological Survey Water Supply Paper, vol. 996.

Jenny, J. P., Wilhelm, B., Arnaud, F., Sabatier, P., Giguet-Covex, C., Mélo, A., ... Perga, M. E. (2014). A 4D sedimentological approach to reconstructing the flood frequency and intensity of the Rhône River (Lake Bourget, NW European Alps). Journal of Paleolimnology, 51(4), 469-483.

Jones, A. F., Macklin, M. G., \& Lewin, J. (2010). Flood series data for the later Holocene: Available approaches, potential and limitations from UK alluvial sediments. The Holocene, 20(7), 1123-1135.

Jones, A. F., Macklin, M. G., \& Brewer, P. A. (2012). A geochemical record of flooding on the upper River Severn, UK, during the last 3750 years. Geomorphology, 179, 89-105.

Kämpf, L., Mueller, P., Plessen, B., Naumann, R., Thoss, H., Güntner, A., ... Brauer, A. (2015). Hydrological and sedimentological processes of flood layer formation in Lake Mondsee. The Depositional Record, 1, 18-37. https://doi.org/10.1002/dep2.2

Kiss, A., \& Laszlovszky, J. (2013). 14th-16th-Century Danube floods and long-term water-level changes in archaeological and sedimentary evidence in the Western and Central Carpathian Basin: An overview with documentary comparison. Journal of Environmental Geography, 6, 1-11. https://doi.org/10.2478/ jengeo-2013-0001 
Kjeldsen, T. R., Macdonald, N., Lang, M., Mediero, L., Albuquerque, T., Bogdanowicz, E., et al. (2014). Documentary evidence of past floods in Europe and their utility in flood frequency estimation. Journal of Hydrology, 517, 963-973. https://doi.org/10.1016/j.jhydrol.2014.06.038

Knox, J. C. (1993). Large increases in flood magnitude in response to modest changes in climate. Nature, 361(6411), 430-432.

Knox, J. C. (2000). Sensitivity of modern and Holocene floods to climate change. Quaternary Science Reviews, 19(1), $439-457$.

Kochel, R. C., \& Baker, V. C. (1982). Paleoflood hydrology. Science, 215, 353-361.

Kochel, R. C., \& Baker, V. R. (1988). Paleoflood analysis using slackwater deposits. In V. R. Baker, R. C. Kochel, \& P. C. Patton (Eds.), Flood geomorphology (pp. 169-187). New York, NY: John Wiley \& Sons.

Kogelnig, B., Stoffel, M., \& Schneuwly-Bollschweiler, M. (2013). Four-dimensional growth response of mature Larix decidua to stem burial under natural conditions. Trees - Structure and Function, 27, 1217-1223.

Kozlowski, T. T. (1997). Responses of woody plants to flooding and salinity. Tree Physiology - Monography, 1, 1-29.

Kuczera, G. (1999). Comprehensive at-site flood frequency analysis using Monte Carlo Bayesian inference. Water Resources Research, 35, $1551-1557$.

Kundzewicz, Z. W., Kanae, S., Seneviratne, S. I., Handmer, J., Nicholls, N., Peduzzi, P., ... Sherstyukov, B. (2014). Flood risk and climate change: Global and regional perspectives. Hydrological Sciences Journal, 59(1), 1-28.

Kundzewicz, Z. W., Krysanova, V., Dankers, R., Hirabayashi, Y., Kanae, S., Hattermann, F. F., .. Schellnhuber, H. J. (2016). Differences in flood hazard projections in Europe - their causes and consequences for decision-making. Hydrological Sciences Journal, 62(1), 1-14. https://doi.org/10.1080/02626667.2016.1241398

Lam, D., Thompson, C., \& Croke, J. (2016). Improving at-site flood frequency analysis with additional spatial information: A probabilistic regional envelope curve approach. Stochastic Environmental Research and Risk Assessment, 31(8), 1-21. https://doi.org/10.1007/s00477-016-1303-x

Lamoureux, S. F. (1999). Spatial and interannual variations in sedimentation recorded in nonglacial varved sediments from the Canadian High Arctic. Journal of Paleolimnology, 21, 73-84.

Lang, M., Ouarda, T. B. M. J., \& Bobée, B. (1999). Towards operational guidelines for over-threshold modeling. Journal of Hydrology, 225, $103-117$.

Lapointe, F., Francus, P., Lamoureux, S. F., Sard, M., \& Cuven, S. (2012). 1750 years of large rainfall events inferred from particle size at East Lake, Cape Bounty, Melville Island, Canada. Journal of Paleolimnology, 48, 159-173.

Levish, D., Ostenaa, D., \& O'Connell, D. (1996). Paleohydrologic bounds and the frequency of extreme floods on the Santa Ynez River, California. California Weather Symposium: A Prehistoric Look at California Rainfall and Floods, 19 pp.

Levish, D. R. (2002). Paleohydrologic bounds-nonexceedance information for flood hazard assessment. In P. K. House, R. H. Webb, V. R. Baker, \& D. R. Levish (Eds.), Ancient floods, modern hazards: Principles and applications of paleoflood hydrology Water science and application (Vol. 5, pp. 175-190). Washington, DC: American Geophysical Union.

Liu, T., Huang, C. C., Pang, J. L., Zhou, Y. L., Zhang, Y. Z., Ji, L., \& Shang, R. Q. (2014). Extraordinary hydro-climatic events during 1800-1600 yr BP in the Jin-Shaan Gorges along the middle Yellow River, China. Palaeogeograhy, Palaeoclimatology, Palaeoecology, 410, 143-152.

Lopez, J., \& Frances, F. (2013). Non-stationary flood frequency analysis in continental Spanish rivers, using climate and reservoir indices as external covariates. Hydrology and Earth System Sciences, 17(8), 3189-3203.

Lumbroso, D., \& Gaume, E. (2012). Reducing the uncertainty in indirect estimates of extreme flash flood discharges. Journal of Hydrology, 414, 16-30. https://doi. org/10.1016/j.jhydrol.2011.08.048

Leese, M. N. (1973). Use of censored data in the estimation of Gumbel distribution parameters for annual maximum flood series. Water Resources Research, 9 , 1534-1542. https://doi.org/10.1029/WR009i006p01534

Macdonald, N., Kjeldsen, T. R., Prosdocimi, I., \& Sangster, H. (2014). Reassessing flood frequency for the Sussex Ouse, Lewes: The inclusion of historical flood information since AD 1650. Natural Hazards and Earth System Sciences, 14, 2817-2828. https://doi.org/10.5194/nhess-14-2817-2014

Macdonald, N., \& Sangster, H. (2017). High-magnitude flooding across Britain since AD 1750. Hydrology and Earth System Sciences, 21, 1631-1650. https://doi. org/10.5194/hess-21-1631-2017

Machado, M. J., Botero, B. A., López, J., Francés, F., Díez-Herrero, A., \& Benito, G. (2015). Flood frequency analysis of historical flood data under stationary and non-stationary modelling. Hydrology and Earth System Sciences, 19, 2561-2576.

Macklin, M. G., Rumsby, B. T., \& Heap, T. (1992). Flood alluviation and entrenchment: Holocene valley floor development and transformation in the British uplands. Geological Society of America Bulletin, 104, 631-643.

Macklin, M. G., Rumsby, B. T., \& Newson, M. D. (1992). Historic overbank floods and vertical accretion of fine-grained alluvium in the lower Tyne valley, north East England. In P. Billi, R. Hey, P. Tacconi, \& C. Thorne (Eds.), Dynamics of gravel-bed rivers (pp. 564-580). Chichester, England: Wiley.

Macklin, M. G., Benito, G., Gregory, K. J., Johnstone, E., Lewin, J., Michcynska, D. J., ... Thorndycraft, V. R. (2006). Past hydrological events reflected in the Holocene fluvial record of Europe. Catena, 66, 145-154.

Macklin, M. G., Toonen, W. H. J., Woodward, J. C., Williams, M. A. J., Flaux, C., Marriner, N., ... Welsby, D. (2015). A new model of river dynamics, hydroclimatic change and human settlement in the Nile Valley derived from meta-analysis of the Holocene fluvial archive. Quaternary Science Reviews, 130, 109-123. https:// doi.org/10.1016/j.quascirev.2015.09.024

Malik, I. (2006). Contribution to understanding the historical evolution of meandering rivers using dendrochronological methods: Example of the Mała Panew River in southern Poland. Earth Surface Processes and Landforms, 31(10), 1227-1245.

Mangili, C., Brauer, A., Moscariello, A., \& Naumann, R. (2005). Microfacies of detrital event layers deposited in quaternary varved lake sediments of the Pianico-Sèllere Basin (northern Italy). Sedimentology, 52, 927-943.

Maréchal, J. C., Ladouche, B., \& Dörfliger, N. (2008). Karst flash flooding in a Mediterranean karst, the example of Fontaine de Nîmes. Engineering Geology, 99, 138-146.

Martinez-Pillado, V., Aranburu, A., Yusta, I., Stoll, H., \& Arsuaga, J. L. (2010). Clima y ocupaciones en la Galeria de Estatuas (Atapuerca, Burgos) en los ultimos 14000 años. Relatos una estalagmita. Munibe, 61, 89-102.

Maas, G. S., \& Macklin, M. G. (2002). The impact of recent climate change on flooding and sediment supply within a Mediterranean mountain catchment, southwestern Crete, Greece. Earth Surface Processes and Landforms, 27, 1087-1105.

Medialdea, A., Thomsen, K. J., Murray, A. S., \& Benito, G. (2014). Reliability of equivalent-dose determination and age-models in the OSL dating of historical and modern palaeoflood sediments. Quaternary Geochronology, 22, 11-24.

Merz, B., Vorogushyn, S., Uhlemann, J., Delgado, J. M., \& Hundecha, Y. (2012). More efforts and scientific rigour are needed to attribute trends in flood time series. Hydrology and Earth System Sciences, 16, 1379-1387.

Merz, B., Aerts, J., Arnbjerg-Nielsen, K., Baldi, M., Becker, A., Bichet, A., ... Nied, M. (2014). Floods and climate: Emerging perspectives for flood risk assessment and management. Natural Hazards and Earth System Sciences, 14, 1921-1942.

Meyer, M. C., Spötl, C., Mangini, A., \& Tessadri, R. (2012). Speleothem deposition at the glaciation threshold d an attempt to constrain the age and paleoenvironmental significance of a detrital-rich flowstone sequence from Entrische Kirche cave (Austria). Paleogeography, Palaeoclimatology, Palaeoecology, $319,93-106$.

Mills, K., Schillereff, D., Saulnier-Talbot, E., Gell, P., Anderson, N. J., Arnaud, F., ... Ryves, D. B. (2016). Deciphering long-term records of natural variability and human impact as recorded in lake sediments: A palaeolimnological puzzle. WIREs Water, 4(2), 1-29. https://doi.org/10.1002/wat2.1195 
Milly, P. C. D., Betancourt, J., Falkenmark, M., Hirsch, R. M., Kundzewicz, Z. W., Lettenmaier, D. P., \& Stouffer, R. J. (2008). Climate change-Stationarity is dead: Whither water management? Science, 319(5863), 573-574.

Minderhoud, P. S. J., Cohen, K. M., Toonen, W. H. J., Erkens, G., \& Hoek, W. Z. (2016). Improving age-depth models of fluvio-lacustrine deposits using sedimentary proxies for accumulation rates. Quaternary Geochronology, 33, 35-45.

Minouri, K., Imarura, F., Sugawara, D., Kono, Y., \& Iwashita, T. (2001). The 869 Jogan tsunami deposit and recurrence interval of large-scale tsunami on the Pacific coast of Northeast Japan. Journal of Natural Disaster Science, 23(2), 83-88.

Mudelsee, M., Börngen, M., Tetzlaff, G., \& Grünewald, U. (2003). No upward trends in the occurrence of extreme floods in Central Europe. Nature, 425, 166-169.

Mudelsee, M., Börngen, M., Tetzlaff, G., \& Grünewald, U. (2004). Extreme floods in Central Europe over the past 500 years: Role of cyclone pathway "Zugstrasse Vb". Journal of Geophysical Research, 109, D23101. https://doi.org/10.1029/2004JD005034

Mudelsee, M. (2014). Climate time series analysis: Classical statistical and bootstrap methods (2nd ed.). Cham, Switzerland: Springer.

Mulder, T., \& Chapron, E. (2011). Flood deposits in continental and marine environments: Character and significance. In R. M. Slatt \& C. Zavalas (Eds.), Sediment transfer from shelf to deep water-Revisiting the delivery system AAPG studies in geology (Vol. 61, pp. 1-30). Tulsa, USA: The American Association of Petroleum Geologists and SEPM.

Munoz, S. E., Gruley, K. E., Massie, A., Fike, D. A., Schroeder, S., \& Williams, J. W. (2015). Cahokia's emergence and decline coincided with shifts of flood frequency on the Mississippi River. Proceedings of the National Academy of Sciences, 112(20), 6319-6324.

Munoz, S. E., \& Dee, S. G. (2017). El Niño increases the risk of lower Mississippi River flooding. Scientific Reports, 7, 1772. https://doi.org/10.1038/ s41598-017-01919-6

Munoz, S. E., Giosan, L., Therrell, M. D., Remo, J. W. F., Shen, Z., Sullivan, R. M., ... Donnelly, J. P. (2018). Climatic control of Mississippi River flood hazard amplified by river engineering. Nature, 556(7699), 95-98. http://doi.org/10.1038/nature26145

Naulet, R., Lang, M., Ouarda, T. B. M. J., Coeur, D., Bobée, B., Recking, A., \& Moussay, D. (2005). Flood frequency analysis on the Ardeche river using French documentary sources from the last two centuries. Journal of Hydrology, 313(1-2), 58-78.

Noren, A. J., Bierman, P. R., Steig, E. J., Lini, A., \& Southon, J. (2002). Millennial-scale storminess variability in the northeastern United States during the Holocene epoch. Nature, 419, 821-822.

O'Connell, D. R. H., Ostenaa, D. A., Levish, D. R., \& Klinger, R. E. (2002). Bayesian flood frequency analysis with paleohydrologic bound data. Water Resources Research, 38(5), 1-13. https://doi.org/10.1029/2000WR000028

O'Connell, D. R. H. (2005). Nonparametric Bayesian flood frequency estimation. Journal of Hydrology, 313(1-2), 79-96.

Ouarda, T., Rasmussen, P., Bobée, B., \& Bernier, J. (1998). Utilisation de l'information historique en analyse hydrologique fréquentielle. Journal of Water Science, 11, $41-49$.

Page, M. J., Trustrum, N. A., \& DeRose, R. C. (1994). A high resolution record of storm-induced erosion from lake sediments, New Zealand. Journal of Paleolimnology, 11, 333-348.

Parris, A. S., Bierman, P. R., Noren, A. J., Prins, M. A., \& Lini, A. (2010). Holocene paleostorms identified by particle size signatures in lake sediments from the northeastern United States. Journal of Paleolimnology, 43, 29-49.

Pfister, C. (2009). The "disaster gap" of the 20th century and the loss of traditional disaster memory. Gaia, 18, 239-246.

Potter, H. R. (1964). Introduction to the history of the floods and droughts of the Trent basin. (Unpublished manuscript). Loughborough.

Pötzsch, C. G. (1784). Chronologische Geschichte der grossen Wasserfluthen des Elbstroms seit tausend und mehr Jahren [Nebst Nachtrug und Fortsetzung]. Dresden, Germany: In der Waltherischen Hofbuchhandlung.

Railsback, B. L., Brook, G. A., \& Webster, J. W. (1999). Petrology and paleoenvironmental significance of detrital sand and silt in a stalagmite from Drotsky's cave, Botswana. Physical Geography, 20, 331-347.

Redmond, K. T., Enzel, Y., House, P. K., \& Biondi, F. (2002). Climate variability and flood frequency at decadal to millennial time scales. In P. K. House, R. H. Webb, V. R. Baker, \& D. R. Levish (Eds.), Ancient floods, modern hazards. Principles and applications of Paleoflood hydrology (pp. 21-45). Washington, DC: American Geophysical Union.

Rigby, R. A., \& Stasinopoulos, D. M. (2005). Generalized additive models for location, scale and shape. Journal of the Royal Statistical Society: Series C: Applied Statistics, 54, 507-544.

Rodbell, D. T., Seltzer, G. O., Anderson, D. M., Abbott, M. B., Enfield, D. B., \& Newman, J. H. (1999). An 15,000- year record of El Nino-driven alluviation in southwestern Ecuador. Science, 283, 516-520.

Rumsby, B. T., \& Macklin, M. G. (1994). Channel and floodplain response to recent abrupt climate change, the Tyne basin, northern England. Earth Surface Processes and Landforms, 19, 499-515.

Rumsby, B. (2000). Vertical accretion rates in fluvial systems: A comparison of volumetric and depth-based estimates. Earth Surface Processes and Landforms, 25, $617-631$.

Sabatier, P., Wilhelm, B., Ficetola, G. F., Moiroux, F., Poulenard, J., Develle, A. L., ... Arnaud, F. (2017). 6-kyr record of flood frequency and intensity in the western Mediterranean Alps e Interplay of solar and temperature forcing. Quaternary Science Reviews, 170, 121-135.

Salinas, J. L., Kiss, A., Viglione, A., Viertl, R., \& Blöschl, G. (2016). A fuzzy Bayesian approach to flood frequency estimation with imprecise historical information. Water Resources Research, 52, 6730-6750. https://doi.org/10.1002/2016WR019177

Sangster, H., Jones, C., \& Macdonald, N. (2018). The co-evolution of historical source materials in the geophysical, hydrological and meteorological sciences: Learning from the past moving forward. Progress in Physical Geography, 42, 61-82.

Schiefer, E., Gilbert, R., \& Hassan, M. A. (2011). A lake sediment-based proxy of floods in the Rocky Mountain front ranges, Canada. Journal of Paleolimnology, 45, $137-149$.

Schillereff, D. N., Chiverrell, R. C., Macdonald, N., \& Hooke, J. M. (2014). Flood stratigraphies in lake sediments: A review. Earth-Science Reviews, 135, $17-37$.

Schulte, L., Veit, H., Burjachs, F., \& Julià, R. (2009). Lütschine fan delta response to climate variability and land use in the Bernese Alps during the last 2400 years. Geomorphology, 108, 107-121.

Schulte, L., Peña, J. C., Carvalho, F., Schmidt, T., Julià, R., Llorca, J., \& Veit, H. (2015). A 2600-year history of floods in the Bernese Alps, Switzerland: Frequencies, mechanisms and climate forcing. Hydrology and Earth System Sciences, 19, 3047-3072.

Seidlmayer, S. J. (2001). Historische und Moderne Nilstände: Untersuchungen zu den Pegelablesungen des Nils von der Frühzeit bis in die Gegenwart. Berlin, Germany: Achet Verlag.

Seneviratne, S. I., Nicholls, N., Easterling, D., Goodess, C. M., Kanae, S., Kossin, J., et al. (Eds.). (2014). A special report of working groups I and II of the intergovernmental panel on climate change (IPCC) (pp. 109-230). Cambridge, England: Cambridge University Press.

Sigafoos, R. S. (1961). Vegetation in relation to flood frequency near Washington, D. C. U. S. Geological Survey Professional Paper, 424-C, 248-249.

Sigafoos, R. S. (1964). Botanical evidence of floods and flood-plain deposition. Professional Paper, 485A. United States Geological Survey. 35 pp

Sivapalan, M., Takeuchi, K., Franks, S. W., Gupta, V. K., Karambiri, H., Lakshmi, V., ... Zehe, E. (2003). IAHS decade on predictions in ungauged basins (PUB), 2003-2012: Shaping an exciting future for the hydrological sciences. Hydrological Sciences Journal, 48(6), 857-880.

Spötl, C., Boch, R., \& Wolf, A. (2011). Eiszeitliche Klimadynamik im Spiegel eines Stalagmiten aus dem Hölloch (Bayern/Vorarlberg). Die Höhle, 62, 1-4. 
St George, S., \& Nielsen, E. (2000). Signatures of high-magnitude 19th-century floods in Quercus macrocarpa tree rings along the Red River, Manitoba, Canada. Geology, 28(10), 899-902.

St. George, S., Nielsen, E., Conciatori, F., \& Tardif, J. (2002). Trends in Quercus macrocarpa vessel areas and their implications for tree-ring paleoflood studies. Tree-Ring Bulletin, 58, 3-10.

St. George, S., \& Nielsen, E. (2003). Palaeoflood records for the Red River, Manitoba, Canada, derived from anatomical tree-ring signatures. Holocene, 13(4), $547-555$.

St George, S. (2010). Tree rings as paleoflood and paleostage indicators. Tree Rings and Natural Hazards: A State-of-the-Art, 41, 233-239. https://doi.org/10.1007/ 978-90-481-8736-2_22

Stedinger, J. R., \& Cohn, T. A. (1986). Flood frequency analysis with historical and Paleoflood information. Water Resources Research, 22, 785-793. https://doi. org/10.1029/WR022i005p00785

Stoffel, M., \& Corona, C. (2014). Dendroecological dating of geomorphic disturbance in trees. Tree-Ring Research, 70, 3-20.

Stokes, S., \& Walling, D. (2003). Radiogenic and isotopic methods for the direct dating of fluvial sediments (pp. 231-267). New York, NY: Wiley.

Støren, E. N., Olaf Dahl, S., Nesje, A., \& Paasche, Ø. (2010). Identifying the sedimentary imprint of high-frequency Holocene river floods in lake sediments: Development and application of a new method. Quaternary Science Reviews, 29, 3021-3033.

Sturm, M., \& Matter, A. (1978). Turbidites and varves in Lake Brienz (Switzerland): Deposition of clastic detritus by density currents. Special Publications of International Association of Sedimentologists, 2, 147-168.

Swierczynski, T., Lauterbach, S., Dulski, P., Delgado, J., Merz, B., \& Brauer, A. (2013). Mid- to late Holocene flood frequency changes in the northeastern Alps as recorded in varved sediments of Lake Mondsee (Upper Austria). Quaternary Science Reviews, 80, 78-90.

Taleb, N. (2010). The black swan: The impact of the highly improbable. New York, NY: Random House.

Tardif, J., \& Bergeron, Y. (1997). Ice-flood history reconstructed with tree rings from the southern boreal forest limit, western Quebec. Holocene, 7(3), 291-300.

Therrell, M. D., \& Bialecki, M. B. (2015). A multi-century tree-ring record of spring flooding on the Mississippi River. Journal of Hydrology, 529, $490-498$.

Thorndycraft, V. R., Benito, G., Rico, M., Sopeña, A., Sánchez-Moya, Y., \& Casas, A. (2005). A long-term flood discharge record derived from slackwater flood deposits of the Llobregat River, NE Spain. Journal of Hydrology, 313(1-2), 16-31.

Tichavský, R., Šilhán, K., \& Stoffel, M. (2017). Age-dependent sensitivity of trees disturbed by debris flows-Implications for dendrogeomorphic reconstructions. Quaternary Geochronology, 42, 63-75. https://doi.org/10.1016/j.quageo.2017.09.002

Timell, T. E. (1986). Compression wood in gymnosperms. Berlin, Germany: Spinger-Verlag.

Toonen, W. H. J., Winkels, T. G., Cohen, K. M., Prins, M. A., \& Middelkoop, H. (2015). Lower Rhine historical flood magnitudes of the last 450 years reproduced from grainsize measurements of flood deposits using end member modelling. Catena, 130, 69-81.

Toonen, W. H. J., Foulds, S. A., Macklin, M. G., \& Lewin, J. (2017). Events, episodes, and phases: Signal from noise in flood-sediment archives. Geology, 45(4), 331-334.

Villarini, G., Smith, J. A., Serinaldi, F., Bales, J., Bates, P. D., \& Krajewski, W. F. (2009). Flood frequency analysis for nonstationary annual peak records in an urban drainage basin. Advances in Water Resources, 32(8), 1255-1266.

Wang, Y., Cheng, H., Edwards, R. L., Kong, X., Shao, X., Chen, S., ... An, Z. (2008). Millennial- and orbital-scale changes in the east Asian monsoon over the past 224,000 years. Nature, 451, 1090-1093.

Werritty, A., Paine, J. L., Macdonald, N., Rowan, J. S., \& McEwen, L. J. (2006). Use of multi-proxy flood records to improve estimates of flood risk: Lower river Tay, Scotland. Catena, 66, 107-119. https://doi.org/10.1016/j.catena.2005.07.012

Wertz, E., St. George, S., \& Zeleznik, J. D. (2013). Vessel anomalies in Quercus macrocarpa tree rings associated with recent floods along the Red River of the north, United States. Water Resources Research, 49(1), 630-634.

Wetter, O., Pfister, C., Weingartner, R., Luterbacher, J., Reist, T., \& Trösch, J. (2011). The largest floods in the high Rhine basin since 1268 assessed from documentary and instrumental evidence. Hydrological Sciences Journall, 56(5), 733-758.

Wetter, O. (2017). The potential of historical hydrology in Switzerland. Hydrology and Earth System Sciences, 21, 5781-5803. https://doi.org/10.5194/ hess-21-5781-2017

White, W. B. (1976). Cave minerals and speleothems. In T. D. Ford \& C. H. D. Cullingford (Eds.), The science of speleology (pp. 267-328). London, England: Academic Press.

Wilhelm, B., Arnaud, F., Sabatier, P., Crouzet, C., Brisset, E., Chaumillon, E., ... Delannoy, J. J. (2012). 1400 years of extreme precipitation patterns over the Mediterranean French Alps and possible forcing mechanisms. Quaternary Research, 78(1), 1-12.

Wilhelm, B., Sabatier, P., \& Arnaud, F. (2015). Is a regional flood signal reproducible from lake sediments? Sedimentology, 62(4), $1103-1117$.

Wilhelm, B., Nomade, J., Crouzet, C., Litty, C., Sabatier, P., Belle, S., ... Anselmetti, F. S. (2016). Quantified sensitivity of small lake sediments to record historic earthquakes: Implications for paleoseismology. Journal of Geophysical Research - Earth Surface, 121, 2-16.

Wilhelm, B., Vogel, H., Crouzet, C., Etienne, D., \& Anselmetti, F. S. (2016). Frequency and intensity of palaeofloods at the interface of Atlantic and Mediterranean climate domains. Climate of the Past, 12, 299-316.

Wilhelm, B., Vogel, H., \& Anselmetti, F. S. (2017). A multi-centennial record of past floods and earthquakes in Valle d'Aosta, Mediterranean Italian Alps. Natural Hazards and Earth System Sciences, 17, 613-625.

Wirth, S. B., Glur, L., Gilli, A., \& Anselmetti, F. S. (2013). Holocene flood frequency across the Central Alps - Solar forcing and evidence for variations in North Atlantic atmospheric circulation. Quaternary Science Reviews, 80, 112-128.

Wong, C. I., \& Breecker, D. O. (2015). Advancements in the use of speleothems as climate archives. Quaternary Science Reviews, $127,1-18$.

Yanosky, T. M., \& Jarrett, R. D. (2002). Dendrochronologic evidence for the fequency and magnitud of palofloods. In P. K. House, R. H. Webb, V. R. Baker, \& D. R. Levish (Eds.), Ancient floods, modern hazards: Principles and applications of paleoflood hydrology: Water science and application (Vol. 5, pp. 77-89). Washington, DC: American Geophysical Union.

Zaginaev, V., Ballesteros-Cánovas, J. A., Erokhin, S., Matov, E., Petrakov, D., \& Stoffel, M. (2016). Reconstruction of glacial lake outburst floods in northern Tien Shan: Implications for hazard assessment. Geomorphology, 269, 75-84.

Zielonka, T., Holeksa, J., \& Ciapala, S. (2008). A reconstruction of flood events using scarred tree in the Tatra Mountains, Poland. Dendrochronologia, 26, 173-183.

How to cite this article: Wilhelm B, Ballesteros Cánovas JA, Macdonald N, et al. Interpreting historical, botanical, and geological evidence to aid preparations for future floods. WIREs Water. 2018;e1318. https://doi.org/10.1002/ wat 2.1318 